DOE/RL-89-12

Revision 1 
LEGAL DISCLAIMER

This report was prepared as an account of work sponsored by an agency of the United States Government. Neither the United States Government nor any agency thereof, nor any of their employees, nor any of their contractors, subcontractors or their employees, makes any warranty, express or implied. or assumes any legal liability or responsibility for the accuracy, completeness, or any third party's use or the results of such use of any information, apparatus, product, or process disclosed, or represents that its use would not infringe privately owned rights. Reference herein 10 any specific commercial producl, process, or service by trade name, trademark, manufacturer, or otherwise, does not necessarily constitute or imply its endorsement, recommendation, or favoring by the United States Government or any agency thereot or its contractors or subcontractors. The views and opinions of authors expressed herein do not necessarily state or reflect those of the United States Government or any agency thereof.

This report has been reproduced from the best available copy. Available in paper copy and microfiche.

Available to the U.S. Department of Energy and its contractors from

Office of Scientilic and Technical Information

P.O. Box 62

Oak Ridge. TN 37831

(615) 576.8401

Available to the public from the U.S. Department of Commerce National Technical Information Service

5285 Port Royal Road

Springfield. VA 22161

(703) $487-4650$

Prinled in the Unitod Stales of America

DISCLM-1.CHP (1.91) 


\title{
Hanford Site Groundwater Protection Management Program
}

Date Published

November 1993

\author{
DISCLAIMER
}

This report was prepared as an account of work sponsored by an agency of the United States Government. Neither the United States Government nor any agency thereof, nor any of their employees, makes any warranty, express or implied, or assumes any legal liability or responsibility for the accuracy, completeness, or usefulness of any information, apparatus, product, or process disclosed, or represents that its use would not infringe privately owned rights. Reference herein to any specific commercial product, process, or service by trade name, trademark, ence heres or otherwise does not necessarily constitute or imply its endorsement, recommanufacturer, or otherwise does not necessarily constitute or imply its endorsement, recommendation, or favoring by the United States Government or any agency thereof. The of the United States Government or any agency thereof.

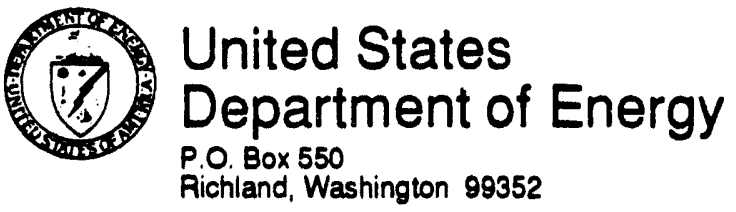




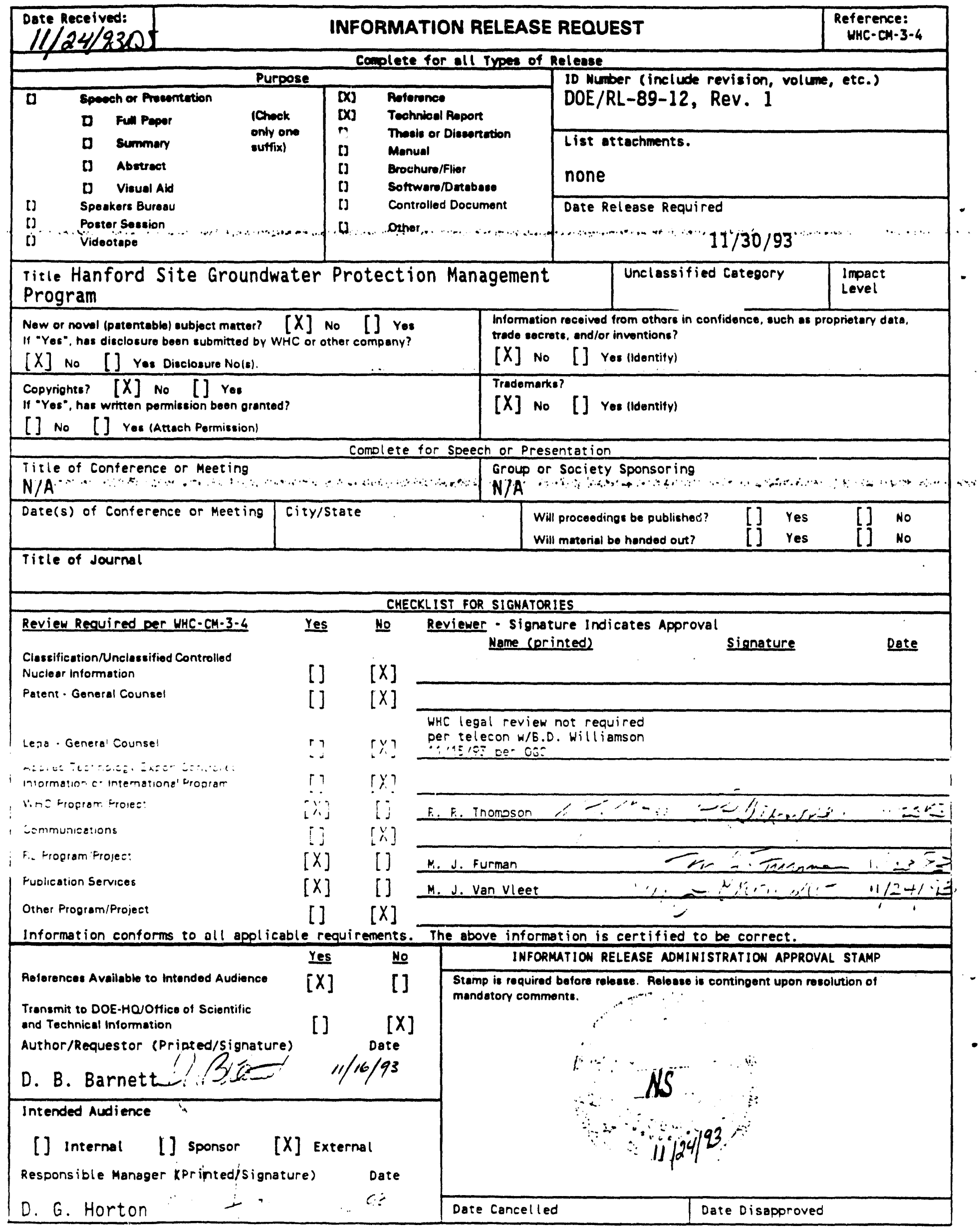




\section{EXECUTIVE SUMARY}

Groundwater protection is a national priority that is promulgated in a variety of environmental regulations at local, state, and federal levels. To effectively coordinate and ensure compliance with applicable regulations, the U.S. Department of Energy has issued DOE Order $5400.1^{1}$ (now under revision) that requires all U.S. Department of Energy facilities to prepare separate groundwater protection program descriptions and plans. This document describes the Groundwater Protection Management Program for the Hanford Site located in the state of Washington.

DOE Order 5400.1 specifies that the Groundwater Protection Management Program covers the following general topical areas: (1) documentation of the groundwater regime, (2) design and implementation of a groundwater monitoring program to support resource management and comply with applicable laws and regulations, (3) a management program for groundwater protection and remediation, (4) a summary and identification of areas that may be contaminated with hazardous waste, (5) strategies for controlling these sources, (6) a remedial action program, and (7) decontamination and decommissioning and related remedial action requirements.

Many of the above elements are covered by existing programs at the Hanford Site; thus, one of the primary purposes of this document is to provide a framework for coordination of existing groundwater protection activities. Additionally, it describes how information needs are identified and can be incorporated into existing or proposed new programs. The Groundwater Protection Management Program provides the general scope, philosophy, and strategies for groundwater protection/management at the Hanford Site. Subtier documents provide the detailed plans for implementing groundwater-related activities and programs. Related schedule and budget information are provided in the 5-year plan for environmental restoration and waste management at the Hanford Site.

The basic groundwater protection strategy for the Hanford Site involves long- and near-term actions. Near-term actions include gradual el imination of liquid waste disposal (to ground) with a target date of 1995. Long-term protection will be accomplished by removal, stabilization, and/or treatment of stored waste and waste released to the ground, and use of engineered barriers to restrict infiltration over disposal sites. Institutional control will also be used tc allow attenuation of existing contaminant plumes. These actions are now part of the formal Hanford Federal Facility Agreement and Consent Order (Tri-Party Agreement) involving the Washington State Department of Ecology, the U.S. Department of Energy, and the U.S. Environmental Protection Agency.

'DOE, 1988, General Environmental Protection Program, DOE Order 5400.1, U.S. Department of Energy, Washington, D.C.

${ }^{2}$ Ecology, EPA, and DOE, 1989, Hanford Federal Facility Agreement and Consent Order, Washington State Department of Ecology, U.S. Environmental Protection Agency, and U.S. Department of Energy, Washington, D.C. 
This page intentionally left blank. 


\section{CONTENTS}

1.0 INTRODUCTION . . . . . . . . . . . . . . . . 1-1

1.1 REGULATORY REQUIREMENTS . . . . . . . . . . . . . . . . . 1-1

1.2 U.S. DEPARTMENT OF ENERGY REQUIREMENTS . . . . . . . . . . $1-1$

1.3 PLANNING DOCUMENTS .................. . . . . . . .

2.0 GROUNDWATER/RESOURCE MANAGEMENT PHILOSOPHY AND GENERAL

INFORMATION NEEDS ...................... 2-1

3.0 GENERAL PROGRAM OBJECTIVES . . . . . . . . . . . . . . . . 3-1

4.0 GROUNDWATER PROTECTION STRATEGY .................. 4-1

4.1 GENERAL POLICY AND STRATEGY ................... 4

4.1.1 Groundwater Protection/Cleanup Standards . . . . . . . . 4-2

4.1.2 Variances . . . . . . . .. . . . . . . . 4-4

4.2 STATE OF WASHINGTON GROUNDWATER REGULATIONS . . . . . . . . . 4-5

4.3 GROUNDWATER ISSUES .................. . . 4-7

4.4 GROUNDWATER PROTECTION AND MONITORING . . . . . . . . . . . 4-7

4.5 LONG-TERM PROTECTION GUIDELINES . . . . . . . . . . . . . 4-8

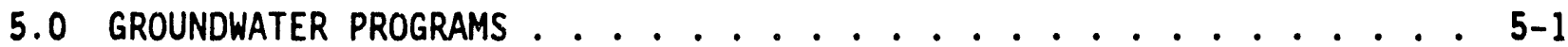

5.1 GROUNDWATER SURVEILLANCE AND MONITORING PROGRAMS . . . . . . 5-1

5.1.1 Program Strategy .. . . . . . . . . . . . . 5-1

5.1.2 RCRA Groundwater Monitoring .. . . . . . . . . 5-4

5.1.3 Operational Monitoring . . . . . . . . . . . 5-4

5.1.4 Groundwater Characterization Under CERCLA . . . . . 5-10

5.1.5 216 Waste Discharge Permit Program . . . . . . . . . 5-10

5.1.6 Underground Storage Tanks Program . . . . . . . . . 5-14

5.1.7 Support Needs . . . . . . . . . . . . . . . 5-14

5.1.8 Subsurface Data Collection Criteria . . . . . . . 5-15

5.2 VADOSE ZONE CHARACTERIZATION AND MONITORING........ . . $5-15$

5.2.1 Net Infiltration ................. 5-16

5.2.2 Contaminant Mobility and Engineered Barriers . . . . . 5-16

5.2.3 Vadose Zone Monitoring Strategy . . . . . . . . 5-18

5.3 PASCO BASIN CONCEPTUAL HYDROLOGIC MODEL . . . . . . . . . 5-20

5.4 INTEGRATION OF PROGRAMS .................. 5-22

5.4.1 Well Administrator Team . . . . . . . . . . . 5-22

5.4.2 Geohydrologic Working Group ............ . 5-23

5.4.3 Hanford Environmental Information System . . . . . 5-23

6.0 IDENTIFICATION AND CONTROL OF HAZARDOUS WASTE SOURCES . . . . . . 6-1

7.0 DECONTAMINATION AND DECOMMISSIONING ACTIVITIES . . . . . . . . 7-1

8.0 IMPLEMENTATION SCHEDULE . . . . . . . . . . . . . . . . 8-1

9.0 REFERENCES ........................... . . 9-1

APPENDIX:

A HANFORD SITE AGREEMENT MANAGEMENT STRUCTURE . . . . . . . . . . A-i 


\section{LIST OF FIGURES}

1-1 Relationship Between the Groundwater Protection Management Program and Other Environmental Protection Programs and Plans Required by DOE Order 5400.1 (DOE 1988) . . . . . . . . . . 1-2

1-2 Correlation of Existing Programs, Plans, and Information with Program Element Requirements in DOE Order 5400.1 (DOE 1988) . . . . 1-4

2-1 Relationship Between Groundwater Protection Regulatory Requirements and Groundwater Management and Compliance Activities ... . . . . . . . . . . . . . . . 2-2

2-2 Groundwater Management Activities and Interrelationships . . . . . 2-3

4-1 Proposed Hanford Site Groundwater Protection and Remediation Strategy . . . . . . . . . . . . . . . . . 4-8

5-1 Projected Relative Change in Groundwater Monitoring Activities at the Hanford Site, 1989 to 2015 . . . . . . . . . . . . 5-2

5-2 Hanford Site RCRA Groundwater Program Process Flowsheet . . . . . 5-5

5-3 Hanford Site Operational Groundwater Program Process Flowsheet . . 5-8

5-4 Strategy for CERCLA Groundwater Remediation and Related Actions at the Hanford Site ................. . 5-11

5-5 Hanford Site CERCLA Groundwater Program Process Flowsheet . . . . 5-12

5-6 Engineered Barrier Functional Performance . . . . . . . . . . 5-17

5-7 Engineered Barrier Development Tasks . . . . . . . . . . . 5-17

5-8 Major Surface Water Features of the Pasco Basin that Influence the Groundwater Regime Beneath the Hanford Site . . . . . . . . 5-21

5-9 Hanford Environmental Information System User Community . . . . . 5-24

6-1 Major Milestones Identified in Tri-Party Agreement Action PIan . . . 6-2

\section{LIST OF TABLES}

1-1 Federal Groundwater Protection-Related Regulations . . . . . . . 1-3

4-1 Washington State Groundwater-Related Regulations . . . . . . . . 4-6

8-1 GPMP Activities and Implementation Schedule . . . . . . . . 8-2 


\section{ACRONYMS}

$A C L$

BAT/AKART

CERCLA

CIP

CFR

DOE

DST

Ecology

EIS

EPA

FS

FY

GPMP

GWG

HEIS

HLW

NEPA

NPDES

PNL

RCRA

RCW

RI

RL

SARA

SST

SWDP

Tri-Party

TRU

Agreement

TSD

UST

WAC

WHC

WHPP alternative concentration limit

Best Available Technology or All known and Reasonable Comprehensive Environmental Response, Compensation, and Liability Act of 1980

Contamination Indicator Parameter

Code of Federal Regulations

U.S. Department of Energy

double-shell tank

Washington State Department of Ecology

Environmental Impact Statement

U.S. Environmental Protection Agency

feasibiiity study

fiscal year

Groundwater Protection Management Drogram

Geohydrologic Working Group

Hanford Environmental Information System

high-level waste

National Environmental Policy Act of 1969

National Pollution Discharge Elimination System

Pacific Northwest Laboratory

Resource Conservation and Recovery Act of 1976

Revised Code of Washington

remedial investigation

DOE, Richland Operations office

Superfund Amendments and Reauthorization Act of 1986

single-shell tank

State Waste Discharge Permit Program

Hanford Federal Facility Agreement and Consent Order transuranic

treatment, storage, or disposal

underground storage tank

Washington Administrative Code

Westinghouse Hanford Company

Washington State Wellhead Protection Program 
This page intentionally left blank. 


\subsection{INTRODUCTION}

This Groundwater Protection Management Program (GPMP) for the Hanford Site fulfills U.S. Department of Energy (DOE) environmental planning requirements outlined in DOE Order 5400.1, General Environmental Protection Program (DOE 1988, p. III-2 and presently under revision). The relationship of the GPMP to other environmental planning documents for the Hanford Site is illustrated in Figure 1-1. Responsibility for implementing DOE's groundwater protection policies is shared by DOE-Headquarters and the DOE, Richland Operations Office (RL) with its contractors. Many of the required activities are already included under DOE's general environmental protection policy and orders to satisfy legally applicable requirements. The primary focus of this document is on development of a framework for coordination of existing groundwater protection programs and activities, and on the process for identifying and correcting program deficiencies.

\subsection{REGULATORY ..EQUIREMENTS}

A number of existing state and federa? environmental regulations include requirements that lead to, or explicitly require groundwater-related plans and programs. Thus, to a large extent, a program that satisfies the above need will be an integration of existing DOE/contractor plans, policies, and procedures that are responsive to: the Washington State Department of Ecology (Ecology) regulations, the U.S. Environmental Protection Agency (EPA) regulations, the state of Washington compliance orders, Consent Orders between Ecology and EPA, and the Comprehensive Environmental Response, Compensation, and Liability Act of 1980 (CERCLA)-related DOE orders. A summary of federal regulatory requirements related to groundwater protection are shown in Table 1-1. In addition, the Hanford Federal Facility Agreement and Consent Order (Ecology et al. 1989) (Tri-Party Agreement) involving EPA, Ecology, and DOE identifies timetables for waste cleanup, which specifies that the groundwater protection provisions of Washington Administrative Code (WAC) 173-303, "Dangerous Waste Regulations," apply to the Hanford Site.

\subsection{U.S. DEPARTMENT OF ENERGY REQUIREMENTS}

DOE Order 5400.1 (DOE 1988) specifies seven general program elements that must be included in a site GPMP. The relationship between these program element requirements and existing Hanford Site environmental documentation is illustrated in Figure 1-2. The matrix diagram shows the program element, corresponding documentation where the subject is addressed, and/or the section number in the GPMP where the subject is discussed. Areas of deficiency or need for additional information are identified in the diagram. 


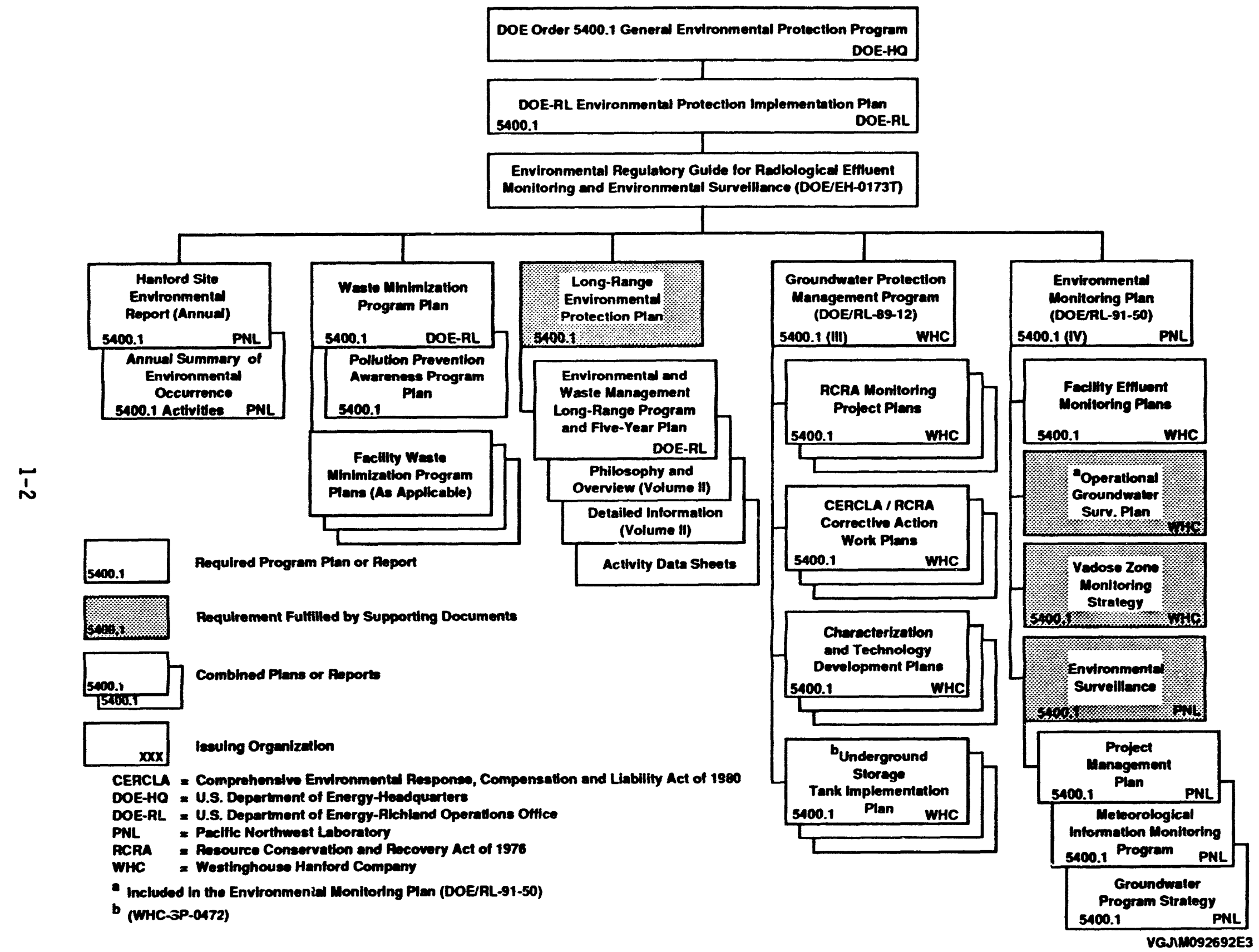

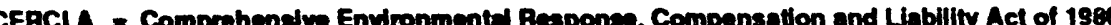

PNL Paelfic Northwest Laboratory

WHC $\quad$ = Westinghouse Hantord Company

- Included in the Environmenial Monitoring PIan (DOE/RL-91-50) 


\begin{tabular}{|c|c|c|c|}
\hline Act & Purpose of act & Rolevence to groundweter & Key repulatione \\
\hline $\begin{array}{l}\text { Rocource Conservation and } \\
\text { Alocovery Act (RCAA) }\end{array}$ & 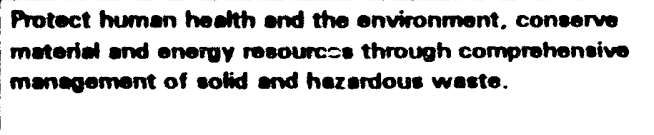 & 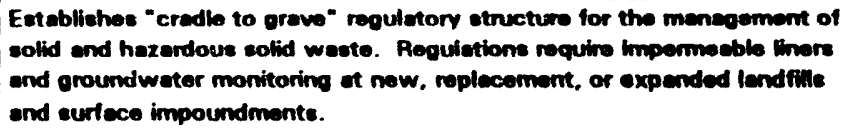 & $\begin{array}{l}40 \text { CFR } 260 . \\
40 \text { CFR } 264-265 . \\
40 \text { CFR } 267\end{array}$ \\
\hline 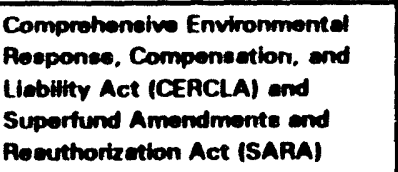 & 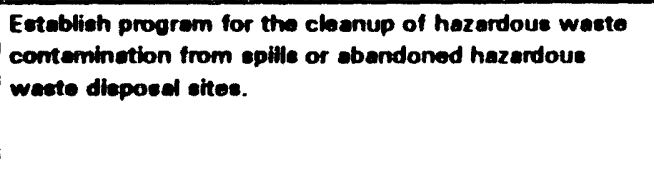 & $\begin{array}{l}\text { Requires cloenup in eccordence with eppliceble or robve } t \text { end } \\
\text { oppropriate aroundwater atenderde. }\end{array}$ & 40 CFR $300-373$ \\
\hline Safe Drinking Water Act (SDWA) & $\begin{array}{l}\text { Euteblish nutional drinking water atandards, protect } \\
\text { oroundwefor coainat contemination, restrict } \\
\text { underonound injoction. }\end{array}$ & 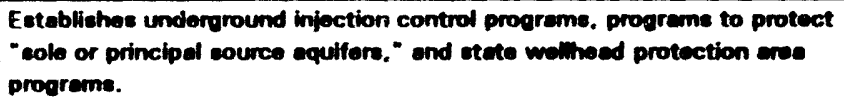 & 40 CFR 144-149 \\
\hline Cloon Weter Act (CWA) & $\begin{array}{l}\text { Postore and maimt in chemical, physical, and biological } \\
\text { inteortity of Nation'a watere. }\end{array}$ & 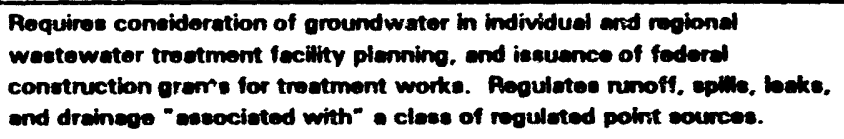 & $\begin{array}{l}40 \text { CFA } 122-125 \\
\text { and } \\
40 \text { CFA 129-130 }\end{array}$ \\
\hline $\begin{array}{l}\text { Nucloer Woate Policy Act } \\
\text { (NWPA) }\end{array}$ & $\begin{array}{l}\text { Eateblish echedulo for the eiting, conetruction. and } \\
\text { operation of high-lovel rediosetive waste repository. }\end{array}$ & 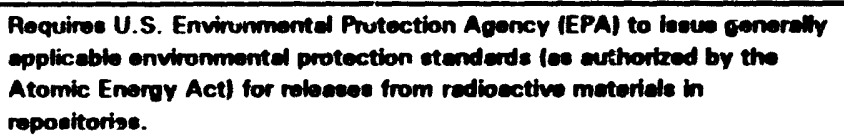 & 40 CFA $191^{\circ}$ \\
\hline $\begin{array}{l}\text { Low-Lovel Redioecetivo Weate } \\
\text { Polley Act }\end{array}$ & 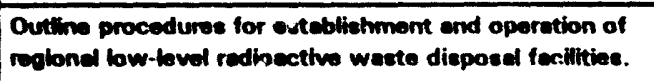 & Indirectly robvent. & 10 CFR $61^{\circ}$ \\
\hline $\begin{array}{l}\text { Urentum Min Tallinge Rediation } \\
\text { Control Act }\end{array}$ & 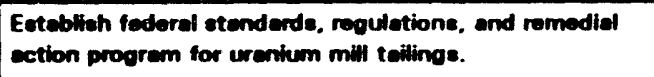 & $\begin{array}{l}\text { Protection of groundwetor from redioective and nonredlosetive } \\
\text { harerdous aubetences must be ensured. }\end{array}$ & 40 CFA 192 \\
\hline $\begin{array}{l}\text { Toxke Subutencee Control Act } \\
\text { (TSCA) }\end{array}$ & 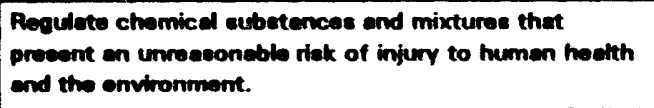 & 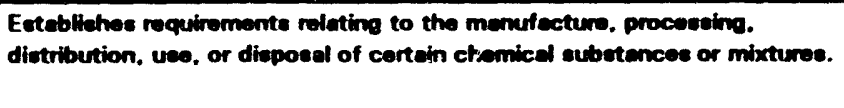 & 40 CFR 761 \\
\hline $\begin{array}{l}\text { Federal meocticlde. Fungicide. } \\
\text { and Plodemticide Act (FIFAA) }\end{array}$ & 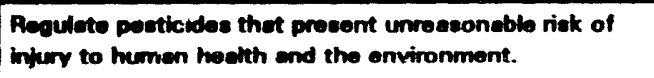 & 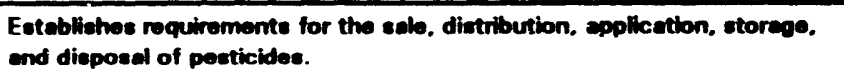 & 40 CFA 162-165 \\
\hline $\begin{array}{l}\text { Atomic Eneror Act (1954), as } \\
\text { omonded }\end{array}$ & 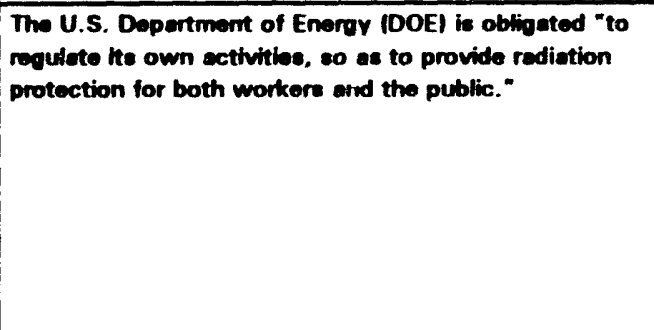 & 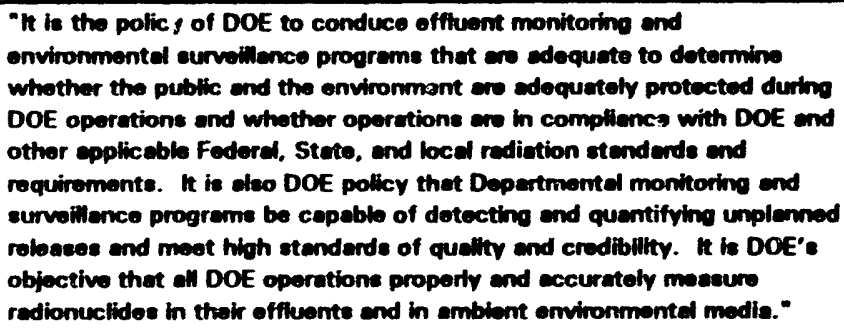 & $\begin{array}{l}\text { DOE Ordere } \\
5400.1 \text { and } \\
5400.5\end{array}$ \\
\hline
\end{tabular}

Note: See Section 9.0. "Poforences." for reference information.

Subpert $B$ of these atenderde halledee groundwater protoction provicione that have been vecated and romanded to EPA by the U.S. Court of Appeate.

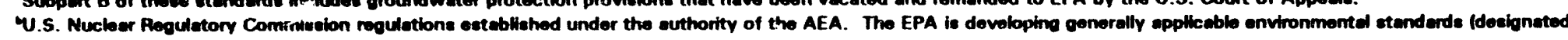
40 CFR 1931 under it: AEA euthority. Both contain groundwater protoction provisione. 
Figure 1-2. Correlation of Existing Programs, Plans, and Information with Program Element Requirements in DOE Order 5400.1 (DOE 1988).

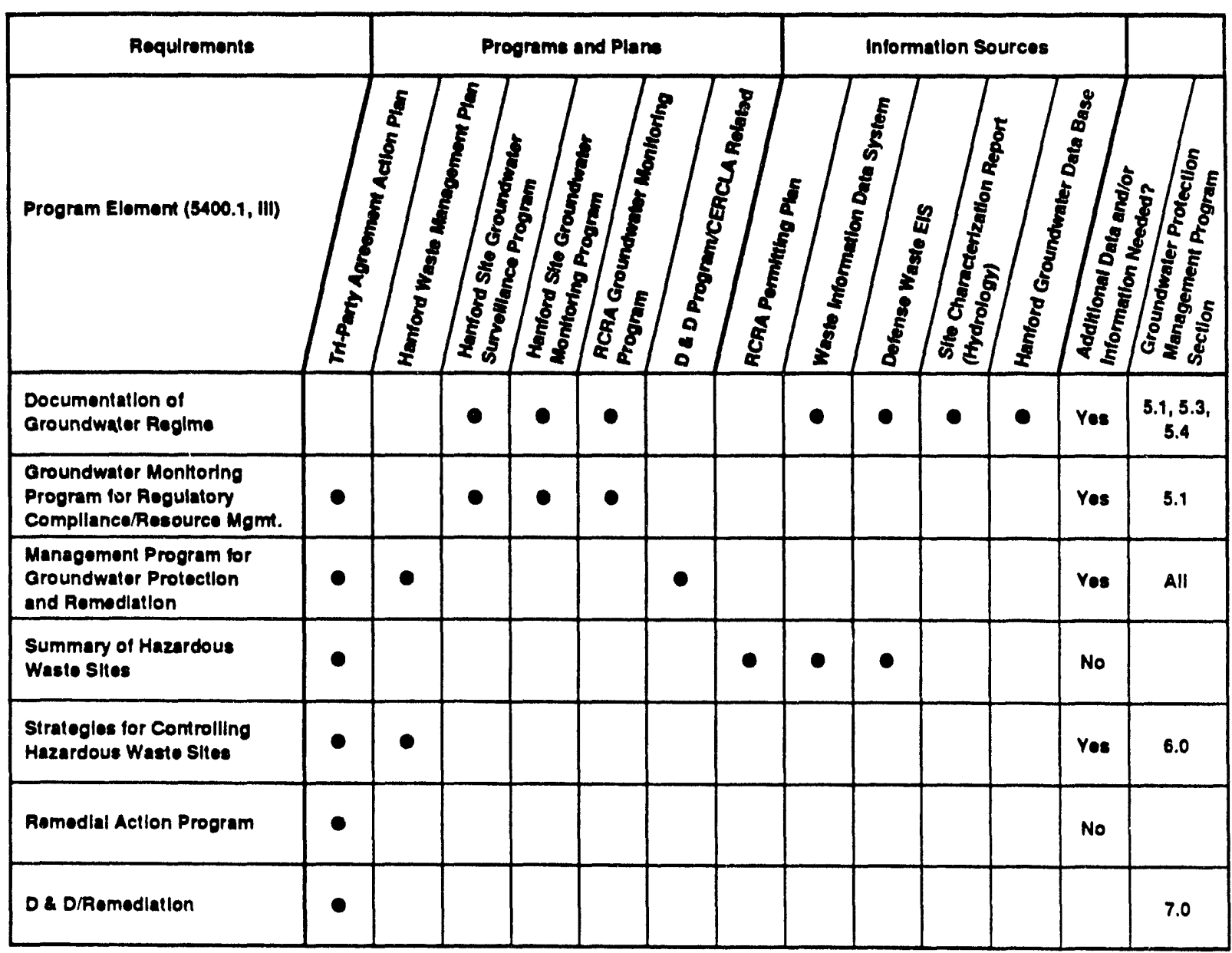

H9210005.3 


\subsection{Planning doCUnENTS}

As shown in Figure 1-1, the GPMP is supported by four major areas of planning documentation: The Resource Conservation and Recovery Act of 1976 (RCRA) groundwater monitoring project plans, the Corrective Action Work Plans, the Characterization and Technology Development Plans, and the Underground Storage Tank Implementation Plan. 
This page intentionally left blank. 


\subsection{GROUNDWATER/RESOURCE MANAGEMENT PHILOSOPHY AND GENERAL INFORMATION NEEDS}

Several state and federal regulations require groundwater protection activities, each with a different overall objective. Common to all, however, is the fundamental need to understand the hydrogeologic system and the dynamic processes involved. Accordingly, the GPMP is based on the belief that a common approach or process should be used regardless of the specific groundwater-related regulation or requirement. This process is illustrated in Figure 2-1 showing the relationship between site missior, regulations, groundwater protection strategy, geotechnical information needs (characterization, modeling, and monitoring), and corrective action or remediation.

Acquisition of geotechnical information is the central focus of groundwater management. Groundwater management at the Hanford Site involves the various activities shown in Figure 2-2. Acquisition of basic hydrogeologic and related information as well as contaminant monitoring results is needed for an understanding of the regulated system. Thus, regardless of whether CERCLA activities, RCRA activities, state-implemented programs, or operational activities are being addressed, the same general information base is needed, as well as a common process for acquiring it. 
Figure 2-1. Relationship Between Groundwater Protection Regulatory Requirements and Groundwater Management and Compliance Activities.

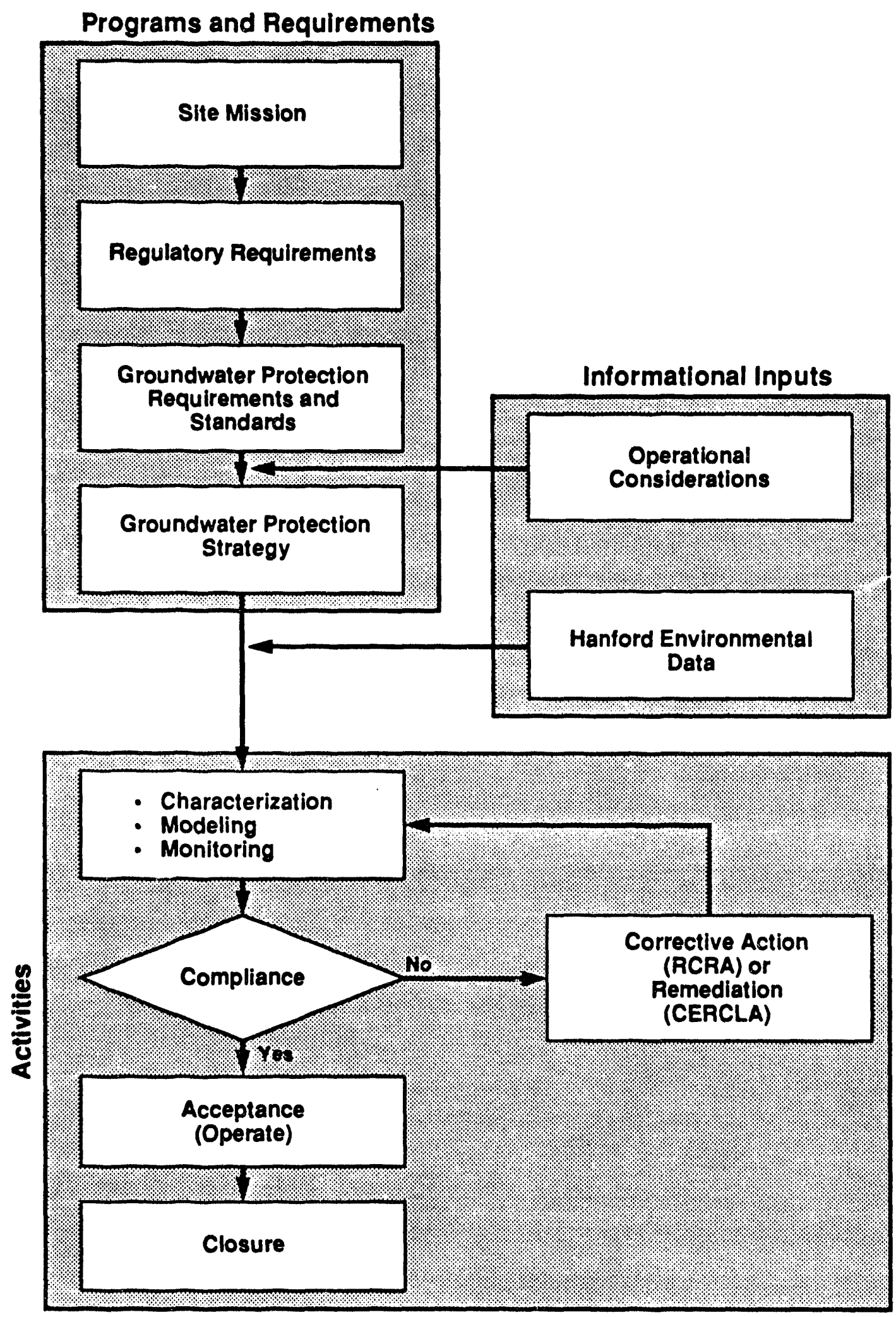

DBBW111293-A 
Figure 2-2. Groundwater Management Activities and Interrelationships.

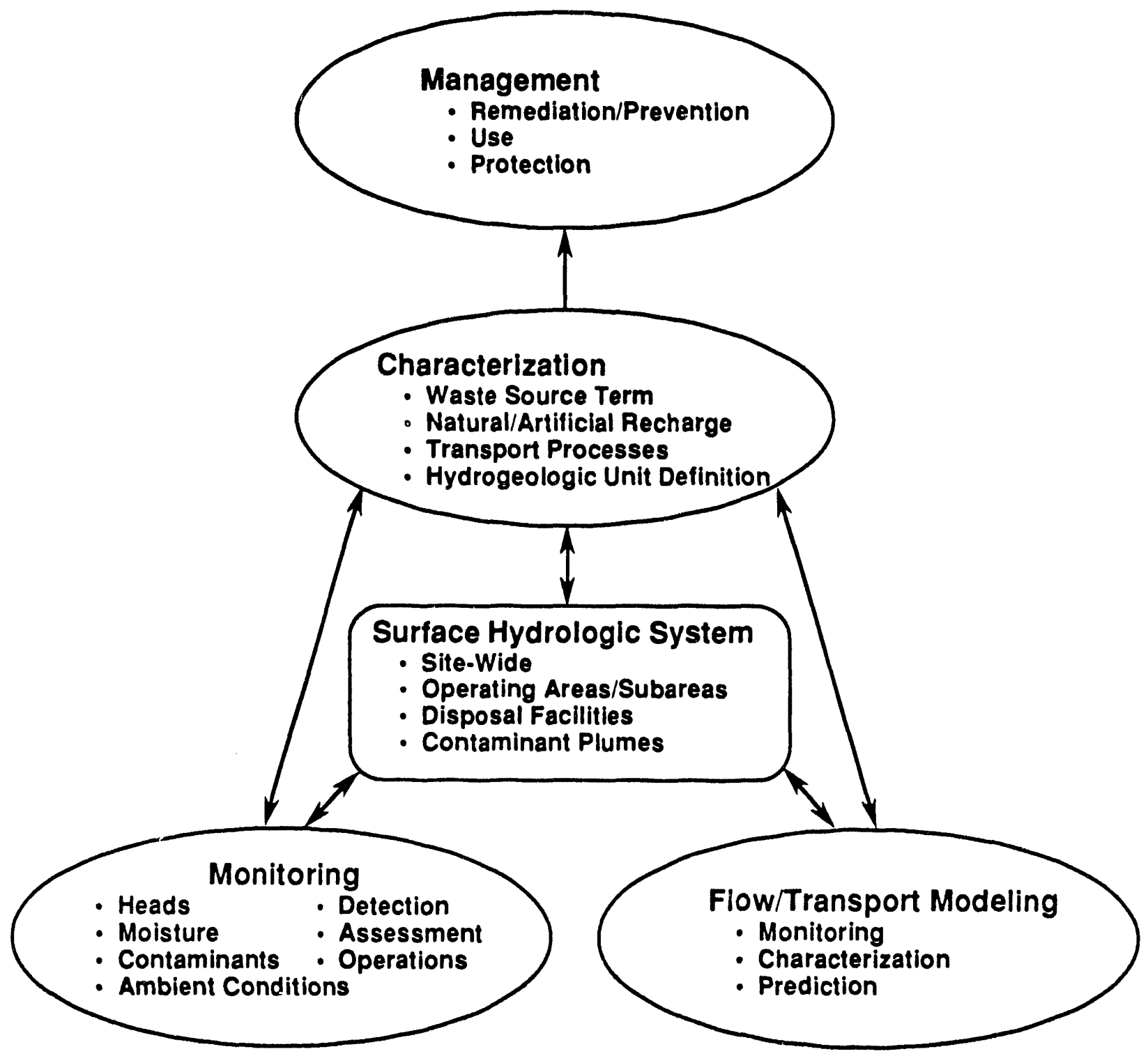

DBBW092093-B 
Rev. 1

This page intentionally left blank. 


\subsection{GENERAL PROGRAM OBJECTIVES}

Within the general objective to ensure adequate environmental protection at all DOE facilities, site-specific objectives for groundwater protection at the Hanford Site include the following:

- Protect the suprabasalt (or unconfined) aquifer from further contamination

- Evaluate upper confined aquifers for existing contamination and potential pathways and interconnectivity with unconfined aquifer

- Manage groundwater (recharge and withdrawal) to minimize adverse impacts of existing contamination

- Assess constraints on offsite migration of contaminants

- Ensure compliance with applicable state of Washington regulations (and federal statutes by reference)

- Determine vadose zone monitoring needs

- Periodically review monitoring programs to ensure cost-effective use of resources (e.g., implement provisions of WAC 173-303-645(b) for "tailoring" monitoring program to site-specific conditions)

- Establish process for identifying information needs. 


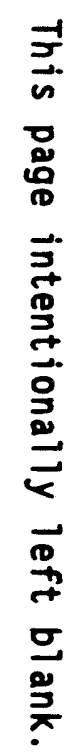




\subsection{GROUNDWATER PROTECTION STRATEGY}

Groundwater protection involves general, DOE-wide as well as sitespecific policy and strategy elements. The general strategy elements are described below. Ecology and Hanford Site (DOE and contractor) policy and standards focus on near-term controls and remediation or corrective action during the period of "institutional control." Long-term protection guidelines and strategy, emphasizing engineered barriers or physical controls, as distinct from actions during the institutional control period, are also described.

\subsection{GENERAL POLICY AND STRATEGY}

Prevention of groundwater contamination is eminently preferable to remediation. However, contamination that has already occurred as a result of past defense-production activities must be addressed. Thus, the DOE general policy is to prevent further groundwater degradation and to clean up existing contamination consistent with current or potential usefulness. Primary reliance will be on physical rather than institutional control for long-term protection.

To accomplish the above objectives, a general strategy that combines source control/elimination with remediation is required. Specific elements of the general DOE strategy from DOE Order 5400.1 (DOE 1988) are listed below.

- Comply with all legally applicable waste management and groundwater protection requirements.

- Voluntarily conform to the EPA's groundwater protection strategy and implementation guidance.

- Systematically review and practice source control to ensure that contaminant releases are as low as reasonably achievable.

- Cooperate with federal and state authorities to promote speedy implementation of RCRA and CERCLA/Superfund Amendments and Reauthorization Act of 1986 (SARA).

- Inform and cooperate with the public on groundwater quality issues.

- Establish DOE groundwater protection standards for new facilities and remedial actions.

- Perform and periodically revise groundwater protection plans for major facilities.

Site-specific strategy elements to accommodate the unique nature of the Hanford Site operations include the following.

- Manage (treat) waste and effluents to minimize or eliminate releases to groundwater. 
- Establish design criteria for early warning, vadose zone monitoring programs, and conduct appropriate groundwater monitoring programs.

- Control artificial recharge and groundwater withdrawals to minimize movement of contaminant plumes.

- Manage soil and vegetative cover to minimize infiltration of direct precipitation over waste sites.

- Provide for acquisition of technical data (aquifer and vadose zone properties and groundwater quality).

- Provide centralized data storage and retrieval.

- Use performance assessment/engineered barriers for risk-based, long-term groundwater protection (in-place stabilization options).

Some of the above strategy elements are partially covered by existing programs within either Westinghouse Hanford Company (WHC) or Pacific Northwest Laboratory (PNL) programs in support of RL directives.

\subsubsection{Groundwater Protection/Cleanup Standards}

4.1.1.1 Remedial Action. Groundwater protection standards for the Hanford Site are based on a policy of nondegradation of groundwater, as defined by the state of Washington groundwater regulations and EPA guidelines. Foremost among remediation and related regulations are the groundwater cleanup standards of "Model Toxics Control Act-Cleanup, "WAC 173-340-720, and the assuciated statistical guidance (Ecology 1992). Additional WACs affecting groundwater remediation and protection are discussed in Section 4.2. The policy of nondegradation prohibits additional or incremental increase in contaminant levels in groundwater, and requires restoration of contaminated groundwater to drinking water standards, "background" levels, or negotiated alternative concentration limits $(A C L)$. Restoration may be preempted if it can be demonstrated that imposed standards would not be exceeded in groundwater during the postclosure period as a result of contaminant interception/attenuation in the vadose zone.

In addition, the proposed revision of 40 Code of Federal Regulations (CFR) 191 and 40 CFR 193 considers the drinking water standard as a primary design performance standard. If engineered barriers are used as part of the cleanup/closure strategy, they must be designed so as to control waste release rates such that the drinking water standard is not exceeded in groundwater.

4.1.1.2 Potential Impact. As indicated previously, the EPA rule governing high-level waste (HLW) and transuranic (TRU) waste disposal is under revision and is expected to include a groundwater protection standard.

The remanded rule required that disposal systems for HLW and TRU waste not cause potential exposures above $4 \mathrm{mrem} / \mathrm{yr}$ (drinking water pathway only) for special sources of groundwater, or $25 \mathrm{mrem} / \mathrm{yr}$ (all pathways) for 
significant sources of groundwater for a period of 1,000 years outside of the controlled area (up to $5 \mathrm{~km}$ beyond the waste area). Waste previously disposed of was excluded.

Waste types potentially subject to the remanded rule included doubleshell tanks (DST), single-shell tanks (SST), and retrievably stored TRU waste. of these, only SST waste might be disposed of in place (decision deferred subject to further analysis and development). Stored TRU waste and the HLW portion of DST waste are to be disposed of offsite. Pre-1970 unsegregated waste and TRU-contaminated soil are excluded as "previously disposed of." Appendix $R$ of the defense waste Environmental Impact Statement (EIS) (DOE 1987) shows that for SST waste, the exposure limits might be exceeded, but not for several thousand years. Thus, it is expected that the remanded rule will have little impact beyond the need for the same additional data, model development, and documentation as that required to support additional decisions and actions under the National Environmental Policy Act of 1969 (NEPA), RCRA, and/or CERCLA.

In connection with the draft 40 CFR 193, it has been suggested that the intention of the EPA is to apply the 4-mrem/yr limit as total (including background and existing plumes) rather than as an increment attributable only to disposal actions under the rule. The limit would become "no additional radioactivity" for areas already above the 4-mrem/yr groundwater limit. This would forbid disposal in such areas because it is not possible to prove "zero" addition with high confidence for several millennia. There are some areas on the Hanford Site where the unconfined aquifer is contaminateo above the 4-mrem/yr limit. This could lead to a prohibition on in-place disposal of SST waste, even if all other conditions were met. However, models of contamination plume migration may demonstrate that plumes are separated in space and/or time, thus averting exceedance of standards.

One important point regarding long-term planning and information needs for groundwater protection is that barrier design and performance validation may be unnecessary if clean closure is required to enforce the nondegradation groundwater rule. That is, if the contaminated soil is removed to background levels or other appropriate cleanup standards, then the need for complex barriers to restrict infiltration becomes unnecessary and clean closure technology should be emphasized rather than surface barriers.

4.1.1.3 Remedial Period. The general DOE-Headquarters guidance is that remedial actions should be completed as rapidly as possible but within 100 years. This implies an institutional control period of 100 years during which contamination within a large portion of the unconfined aquifer would be attenuated because of dispersion and transport to the river. The Hanford Site proposes to use the institutional control provision and control of access to the uppermost aquifer as part of its groundwater protection and remediation strategy.

4.1.1.4 Point of Compliance. Compliance points specify the locations at which compliance with groundwater contamination standards is enforced. The compliance point works in concert with standards; "compliance point" relates to the extent of the protected environment; "standards" refer to the level of protection. Compliance points may be useful as part of the specifications for the design of new facilities (at least where complete containment of 
contaminants is not reasonably achievable). Monitoring is conducted at the compliance point to demonstrate compliance and to help provide early warning of any groundwater contamination.

Regulatory agencies have established different compliance point conventions in different rulemakings (e.g., 40 CFR 264, 40 CFR 61). Some conventions permit a horizontal and vertical "buffer zone" between a contaminant source, such as a waste disposal area, and the compliance point. In effect, this incorporates the absorbing and diluting properties of adjacent earth and groundwater as part of the disposal system. The RCRA convention is most restrictive, however, and virtually forbids buffer zones. The RCRA regulations provide an almost equivalent feature (i.e., an alternate concentration limit) only as a site-specific variance, where a contaminant release "...will not pose a substantial present or potential hazard..."

The DOE's policy is to conform to such established conventions as they apply to its operations and facilities. When DOE has the discretion, it will choose compliance points as close to the contaminant source as is reasonably achievable, but not outside the boundaries of its facilities.

\subsubsection{Variances}

Most environmental standards include provisions for "tailoring" regulations to site-specific hydrogeologic conditions. This is especially important at the Hanford Site where recharge is low because of the arid climate and the distance to groundwater is great beneath a major portion of the area in which waste sites are located. For example, there is little to be gained by installing groundwater monitoring wells in areas where past experience (Routson and Johnson 1988) and performance assessment demonstrates long travel times to groundwater ( $>50$ years). In these locations, vadose zone and/or leachate collection monitoring are more relevant as an "early warning" monitoring system for groundwater protection. Reliance on groundwater monitoring in these cases is potentially misleading because a slow-moving leachate would not be detected until the entire vadose zone beneath a waste site is contaminated.

Other special cases at the Hanford Site involve potentially rapid removal of existing groundwater contamination by natural flushing processes, especially for waste sites located near the Columbia River. Similarly, existing contaminant plumes in highly transmissive sands and gravels downgradient from the 200 East Area will attenuate within the institutional control period because of natural dispersion and transport processes. Allowance for such processes will be considered part of the remedial action strategy.

The site-specific hydrogeology and waste form or disposal conditions must be analyzed in a systematic manner before reaching a decision on an appropriate subsurface monitoring system for each waste site. If these analyses are in conflict with regulatory interpretations, they will be resolved by negotiation with EPA and Ecology in accordance with procedures established in the Tri-Party Agreement. Such requests for deviation from prescriptive regulatory requirements must be supported with performance assessments and adternative subsurface monitoring plans. 


\subsection{STATE OF MASHINGTON GROUNDWATER REGULATIONS}

Since the last version of this document was produced, the state has finalized several new WACs, or revised versions thereof, regulating groundwater quality and quantity. Additional new codes are in various stages of formulation or review. These regulations and their implications for groundwater management are summarized in Table 4-1.

Ecology administers most of the new codes that affect the management and protection of the state's groundwater. These include WAC 173-200, Water Qual ity Standards for Ground Waters for the State of Washington," WAC 173-360, "Underground Storage Tank Regulations," and WAC 173-340, "Model Toxics Control Act-Cleanup." Also, in accordance with Tri-Party Agreement Milestone M-17-13, WAC 173-240, "Submission of PIans and Reports for Construction of Wastewater Facilities," and WAC 173-216, "State Waste Discharge Permit Program," sites receiving i iquid effluents must be assessed for impact on groundwater quality and satisfy the appropriate permitting requirements. Although the Hanford Site Solid Waste Landfill is managed under the RCRA program, actual requirements for groundwater monitoring for this facility are governed by WAC 173-304, "Minimum Functional Standards for Sol id Waste Handling."

Rules addressing hydraulic continuity between surface water and groundwater are undergoing formulation and public review under the firection of Ecology, Water Resources Program. Although hydraulic continuit, regulations will focus on degree of exchange of quantities of surface water and groundwater, quality impairment will also be addressed as provided in the empowering laws (Revised Code of Washington [RCW]), including "Water Resources Act of 1971" (RCW 90.54) and "Regulation of Public Ground Waters" (RCW 90.44). Water resources laws al so authorize other potentialiy pertinent administrative codes, such as WAC 173-154, "Protection of Upper Aquifer Zones," and WAC 173-160, "Minimum Standards for Construction and Maintenance of Wells."

The federal Endangered Species Act of 1973 has recently triggered the implementation of state emergency rules protecting salmonids on the main steris of the Columbia River and Snake River (WAC 173-563 and WAC 173-564). Ecology has suspended the issuance of surface water rights/permits on these rivers, and any groundwater adjudged to be in hydraulic continuity with the rivers.

Mostly as a result of the "Growth Management Act" (Department of Community Development 1990), other Washington State agencies have recently or will soon implement rules directly or peripherally affecting statewide groundwater management. The Washington State Department of Health has assumed the role of lead agency for administering the Washington State Wellhead Protection Program (WHPP); no specific administrative code yet exists. For now, other state and local agencies will have "source-specific" jurisdictions over the implementation of the WHPP and regulation of sources of potential contamination to wells (e.g., Ecology has regulatory responsibility for underground storage tanks and dangerous waste generators). The Washington State Department of Community Development administers WAC 365-190, "Minimum Guidelines to Classify Agriculture, Forest, Mineral Lands, and Critical Areas." These guidel ines contain provisions for protection of "aquifer recharge areas" (under a general heading of "Critical Areas"). 
Table 4-1. Washington State Groundwater-Related Regulations.

\begin{tabular}{|c|c|c|c|}
\hline Aegulation (Leteet version) & $\begin{array}{l}\text { Aeeponaible } \\
\text { otete ecenoy }\end{array}$ & Purpese of reouletion & Alelevenoe to oroundwater \\
\hline $\begin{array}{l}\text { "Wator Quality standerde for Ground } \\
\text { Watere tor the state of Weehington" } \\
\text { (WAC 173-200) (1890) }\end{array}$ & Eeolegy & $\begin{array}{l}\text { Eatabliahe minimum quality otandarde for } \\
\text { groundwator. Implements RCW } 00.48 \text { and } \\
\text { RCW } 00.54 \text {. }\end{array}$ & $\begin{array}{l}\text { Impeece groundwater quality oriterie for } \\
\text { primery and ecoondary conteminant } \\
\text { and eome redionuolides. }\end{array}$ \\
\hline $\begin{array}{l}\text { "Woter Quality Stendarde or Eurices } \\
\text { Weters of the state of Weshington" } \\
\text { (WAC } 173-201)(1089)\end{array}$ & Eoology & $\begin{array}{l}\text { Eatablisher woter quality etanderde ind } \\
\text { clesece for surfece watere of Weehington } \\
\text { state. }\end{array}$ & $\begin{array}{l}\text { Surfeces weter and groundweter are } \\
\text { often in direet communiontion. }\end{array}$ \\
\hline $\begin{array}{l}\text { "Undoraround Storege Tank } \\
\text { Rogulations" (WAC 173-380) (1980) }\end{array}$ & Eoology & 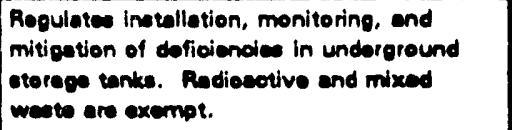 & $\begin{array}{l}\text { Require ownera/operaton of } \\
\text { undorground etorege tanke to menitor } \\
\text { groundwoter avelity. }\end{array}$ \\
\hline $\begin{array}{l}\text { "Dangoroun Wente Regulations" } \\
\text { (WAC 173-303) } 119911\end{array}$ & Ecologr & $\begin{array}{l}\text { Implemente rules tor dalenoting. } \\
\text { monitoring, and menaging dengereu } \\
\text { wevte. }\end{array}$ & $\begin{array}{l}\text { Requires ownen/operetore of fecilitien } \\
\text { to oonduot groundwetor quelity } \\
\text { monitoring and respones progrem. }\end{array}$ \\
\hline $\begin{array}{l}\text { "Minimum Functional Standarde for } \\
\text { Solid Weate Handling" (WAC 173-304) } \\
\text { (1888) }\end{array}$ & Ecoloor & 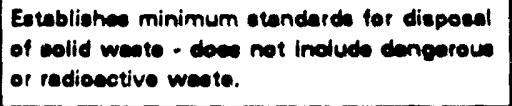 & 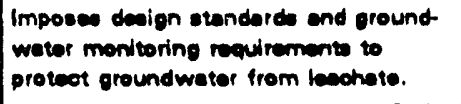 \\
\hline $\begin{array}{l}\text { "Srate Weate Dischares Permil } \\
\text { Program" (WAC 173-216) (1093) }\end{array}$ & Eooloor & $\begin{array}{l}\text { Implements permit pregrem epplying to } \\
\text { discharge of whete to surfecs watere and } \\
\text { groundweter under RCW } 0.48 \text {. }\end{array}$ & $\begin{array}{l}\text { Controle diecheres of weete to } \\
\text { groundwotor. }\end{array}$ \\
\hline $\begin{array}{l}\text { "Model Toxien Control Aot-Clemenup" } \\
\text { (WAC 173-340) (1902) }\end{array}$ & Ecology & $\begin{array}{l}\text { Governs the charecterizetion and deanup of } \\
\text { hazardow eubetanos releces. }\end{array}$ & $\begin{array}{l}\text { Requires groundwator oyetem } \\
\text { oharecterizotion end groundwater } \\
\text { quality eseceement at regulated oitee. }\end{array}$ \\
\hline $\begin{array}{l}\text { "Submisaion of Piens and Reports for } \\
\text { Conmtruction of Westowotor Fecilities" } \\
\text { (WAC 173-240) (1083) }\end{array}$ & Eoologr & $\begin{array}{l}\text { Implements RCW } 90.48 \text { - requires oubmie- } \\
\text { sion of plen and reports for contruction of } \\
\text { modificetion of wentewater teolities. }\end{array}$ & $\begin{array}{l}\text { Requires "ecohydrologic" evelwation in } \\
\text { engineoring report. }\end{array}$ \\
\hline $\begin{array}{l}\text { "Ground Weter Managernent Areee and } \\
\text { Programe" (WAC 173-100) (1988) }\end{array}$ & Eoology & $\begin{array}{l}\text { Allowe Ecolugy to deaignate arees with } \\
\text { peculier nead for groundwoter } \\
\text { manegement; deo a funding mechaniem. }\end{array}$ & $\begin{array}{l}\text { Forgee cooperative manocoment } \\
\text { program for groundwater botween } \\
\text { looel, otate, tribal, and fedoral intereats. }\end{array}$ \\
\hline $\begin{array}{l}\text { "Minimum standarda for Construotion } \\
\text { end Maintenanos of Welle" } \\
\text { (WAC } 173-180)(1093)\end{array}$ & Eoology & $\begin{array}{l}\text { Sote otendarde for drilling and water well } \\
\text { conotruction. }\end{array}$ & $\begin{array}{l}\text { Protects groundwoter quality from } \\
\text { impairment by intermingling of } \\
\text { groundwoton or wellinesd eurfece } \\
\text { contemination. }\end{array}$ \\
\hline $\begin{array}{l}\text { "Water Rewouroes Act of 1971" } \\
\text { (RCW } 00.54)(1981)\end{array}$ & Ecology & $\begin{array}{l}\text { Stetutory suthority for regulation of water } \\
\text { resouroes. }\end{array}$ & $\begin{array}{l}\text { Groundwater recognized ee integral to } \\
\text { protection of state watere. }\end{array}$ \\
\hline $\begin{array}{l}\text { "Reoulation of Public Ground Wotere" } \\
\text { (ACW } 80.44)(1989)\end{array}$ & Eoologr & $\begin{array}{l}\text { Stututory euthority for regulation of } \\
\text { groundwoter/water rights. }\end{array}$ & $\begin{array}{l}\text { Prohibite mieuse of groundwator } \\
\text { throwgh waste or degradation of } \\
\text { quality. }\end{array}$ \\
\hline $\begin{array}{l}\text { "Undorground Injection Control Plan" } \\
\text { (WAC 173-218) (1990) }\end{array}$ & Eoologr & $\begin{array}{l}\text { Earablione procedures/prectioes } \\
\text { implementing requirements of RCW e0.44 } \\
\text { end fedorel "Safo Drinking Woter Aot } \\
\text { of } 1874 \text {." }\end{array}$ & $\begin{array}{l}\text { Controle the diecherge of weste or } \\
\text { hormflul fluide to groundweter through } \\
\text { wedle. }\end{array}$ \\
\hline $\begin{array}{l}\text { "Protection of Withdrewal Fecilities } \\
\text { Aesociated with Ground Wetse Rightse" } \\
\text { (WAC 173-150) (1980) }\end{array}$ & Ecology & $\begin{array}{l}\text { Protects oveilability and auclity of } \\
\text { groundwator to the fecilities of holdere of } \\
\text { groundwoter rights. }\end{array}$ & $\begin{array}{l}\text { Protect groundwater right holders } \\
\text { from impairment by contemination or } \\
\text { depletion. }\end{array}$ \\
\hline $\begin{array}{l}\text { "Protcotion of Uppor Aquifer Zonme" } \\
\text { (WAC 173-184) (1088) }\end{array}$ & Eooleor & $\begin{array}{l}\text { Protection of the ocourrence and evellability } \\
\text { of groundwater within the uppor equifore. }\end{array}$ & $\begin{array}{l}\text { Proteoti neweurfeces groundwater } \\
\text { from deplotion of quality impaiment. }\end{array}$ \\
\hline $\begin{array}{l}\text { "Minimum Guidedines to Cleneity } \\
\text { Agriculture, Forest, Miroral Lends and } \\
\text { Critioal Arees" (WAC 305-100) (198) }\end{array}$ & $\begin{array}{l}\text { Community } \\
\text { Development }\end{array}$ & 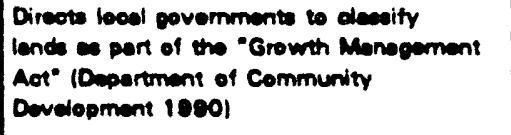 & $\begin{array}{l}\text { Requires ditien and countien to deesity } \\
\text { equifer recharge arees. }\end{array}$ \\
\hline $\begin{array}{l}\text { "On-Eite Eovrege Dispoeal" } \\
\text { (WAC 246-272) (1090) }\end{array}$ & Heolth & Reoulates ondite eeptic eveteme. & $\begin{array}{l}\text { Eatablishes zone of eeperation botween } \\
\text { drainfielde and groundwotor. }\end{array}$ \\
\hline $\begin{array}{l}\text { "Wellhead Protection Progrem" (no } \\
\text { cotabliehed codes es of Oro2). }\end{array}$ & Health & $\begin{array}{l}\text { Adminiatare to other egenoies through } \\
\text { exieting, souroo-apecific regulations. }\end{array}$ & $\begin{array}{l}\text { Secke to provent contemination of } \\
\text { proundwoter vis routes neat welliheade. }\end{array}$ \\
\hline
\end{tabular}




\subsection{GROUNDWATER ISSUES}

The Tri-Party Agreement defined a cleanup schedule for hazardous waste at the Hanford Site (Ecology et al. 1989). The groundwater protection/monitoring aspects of the Tri-Party Agreement must be technically defensible and not simply "prescriptive" (see Section 4.1.2). For example, in many cases groundwater monitoring wells may not be the most effective approach for assessing potential groundwater contamination and may not provide the desired or expected early warning system envisioned by the regulatory requirements (WAC 173-303-645, "Releases From Solid Waste Management Units"). In many cases at the Hanford Site, only a vadose monitoring system will provide this type of information. Thus, a systematic approach is needed to design the most appropriate subsurface monitoring facilities (e.g., use of performance assessment models of waste sites).

Near-term emphasis is on: (1) characterizing the occurrence and distribution of existing vadose zone and groundwater contaminants and on defining the groundwater flow system, and (2) determining if a vadose zone monitoring system would better serve the need of compliance point monitoring and groundwater protection.

\subsection{GROUNDWATER PROTECTION AND MONITORING}

Effluent monitoring is used to determine the character of waters discharged to the ground. Groundwater monitoring programs are instituted to verify compliance with regulations and orders and to track past contaminant releases that may require remediation through the CERCLA process. Results of these activities are published annually in effluent and groundwater monitoring reports.

Groundwater monitoring is the key activity for ensuring adequacy of groundwater protection measures and strategies. The basic strategy for "nearterm" groundwater protection at the Hanford Site is summarized as follows.

- Reduce or eliminate contaminants in liquid effluent to 1 imit releases to drinking water standards.

- Allowance for radioactive decay during the period of "institutional control."

- Remediation and/or attenuation to meet drinking water standards (or $A C L s$ ) at the end of the period of institutional control (assumed to be the year 2150).

This strategy is illustrated in Figure 4-1. The bell-shaped distribution of hypothetical contaminants represents the centerline concentration(s) of a plume moving toward the Columbia River during the institutional control period. The objective concentration (horizontal dashed line indicating either the maximum contaminant level or drinking water standard) is shown for reference. The portion of the plume that requires remediation is shown as the shaded area of the initial (1988) concentration-distance distribution curve. The dashed bell-shaped curve at the discharge boundary (Columbia River) illustrates possible contaminant attenuation caused by dispersion and/or 
Figure 4-1. Proposed Hanford Site Groundwater Protection and Remediation Strategy.

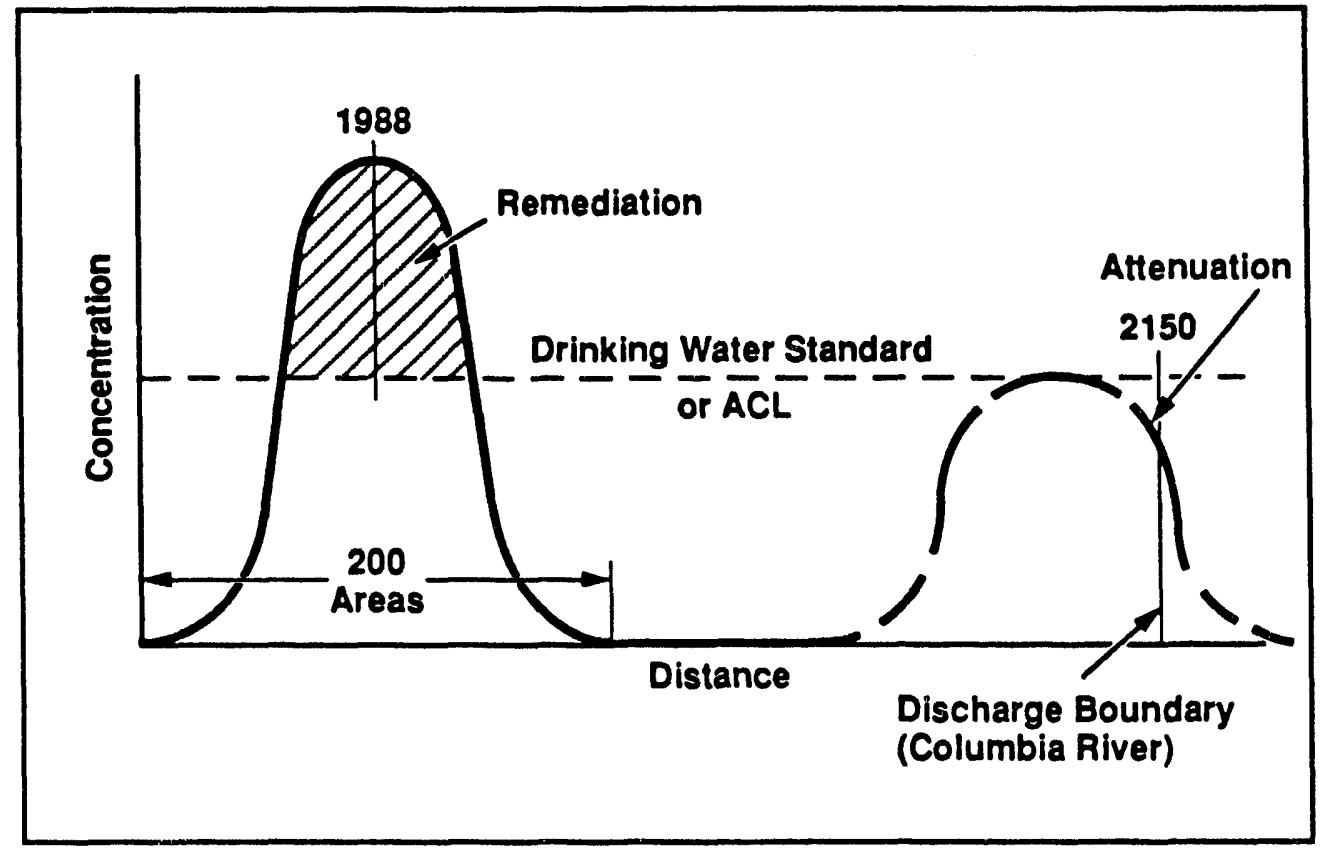

H9310014.1

radioactive decay. Thus, depending on the nature and concentration of the contaminant, remediation in the near term to reduce contaminant levels to either drinking water standards or a negotiated $A C L$ will take advantage of decay and dilution to ensure compliance with CERCLA requirements.

\subsection{LONG-TERM PROTECTION GUIDELIMES}

Many constituents that have been disposed (or leaked) into the vadose zone from past Hanford Site operations will remain indefinitely because they are either chemically stable or have a very long half-life. Because stability of human institutions cannot be predicted, institutional control is unacceptable for long-term protection. Thus, DOE's policy is to rely primarily on physical control methods (or source removal) for long-term groundwater protection. Institutional controls will be 1 imited to 100 years as discussed previously. Both risk and control (or performance) assessments will be used to project long-term performance of disposal methods. The projection period used will be at least 1,000 years.

Engineered barrier designs will be used with other technologies (e.g., hydraulic control of contaminant plumes) to maintain contaminant concentrations in groundwater at less than drinking water standards during the projection period. For radionuclides, the design performance standard may be based on a dose rate (drinking water pathway) standard of $4 \mathrm{mrem} / \mathrm{yr}$ from all sources (see Section 4.1.2). For nonradioactive contaminants, state-imposed drinking water standards or ACLs will be design performance criteria. 
Demonstration of compliance with the above requirements will be based on performance assessments that require realistic predictive models and assignment or determination of input parameters such as net infiltration rate, climatic changes (precipitation), and sorptive properties of soils and sediments. These factors are part of the ongoing Hanford Site performance assessment and barrier development programs. 


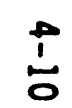

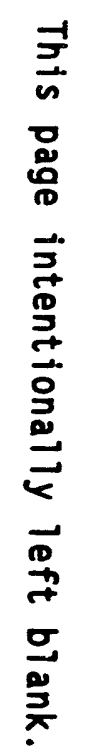




\subsection{GROUNDWATER PROGRAMS}

This section describes (1) existing groundwater protection, management, and related monitoring programs; (2) associated hydrogeologic characterization needs/guidelines; and (3) a strategy and policy for integrating the various groundwater monitoring and management activities at the Hanford Site.

\subsection{GROUNDWATER SURVEILLANCE AND MONITORING PROGRAMS}

Groundwater monitoring, consisting of chemical constituent analyses and water level measurements, is a key element of any groundwater protection program. At the Hanford Site, this currently invoives (1) sitewide surveillance to track contaminant plume movement from past disposal operations, (2) compliance or operational monitoring of active liquid waste disposal sites, (3) permit-related monitoring for RCRA-regulated facilities, (4) CERCLA-related remedial investigation studies, (5) Washington State 216 Permit monitoring, and (6) Washington underground storage tank (UST) monitoring.

PNL is responsible for the sitewide groundwater surveillance (monitoring) program at the Hanford Site. This program provides an integrated assessment of the impact of site operations on the groundwater system. Assessment is performed independently of programs administered by the site operating contractor. The need for an independent assessment of groundwater quality on the site will remain throughout the period of cleanup activities and during the postclosure monitoring phase.

WHC has responsibility for operational, RCRA, CERCLA, 216 Permit, and UST groundwater programs. Operational monitoring primarily assesses the performance of liquid waste disposal systems (soil column) for which monitoring wells were located immediately adjacent to the facility. In the future these programs will shift to an independent assessment and reporting of data acquired for RCRA and CERCLA programs. This will occur as operational monitoring activities diminish in response to cleanup milestones and schedules for elimination of soil column disposal of liquid waste streams. As CERCLA characterization proceeds, some wells no longer needed for that program may become designated to the operational program. This changing relationship is illustrated in Figure 5-1. These phases represent a natural evolution of compliance monitoring, discovery, characterization, remediation (or corrective action), and cleanup verification. The transition among these phases will require aggressive coordination among the various organizations and programs over the next 30 years until final cleanup and closure of Hanford Site waste sites.

\subsubsection{Program Strategy}

Battelle-Northwest, the operator of PNL for the DOE, is responsible for environmental oversight of the Hanford Site operations. The plan for conducting groundwater environmental surveillance on the Hanford Site has been developed by Battelle-Northwest and is summarized in the following paragraphs. 
Figure 5-1. Projected Relative Change in Groundwater Monitoring Activities at the Hanford Site, 1989 to 2015.

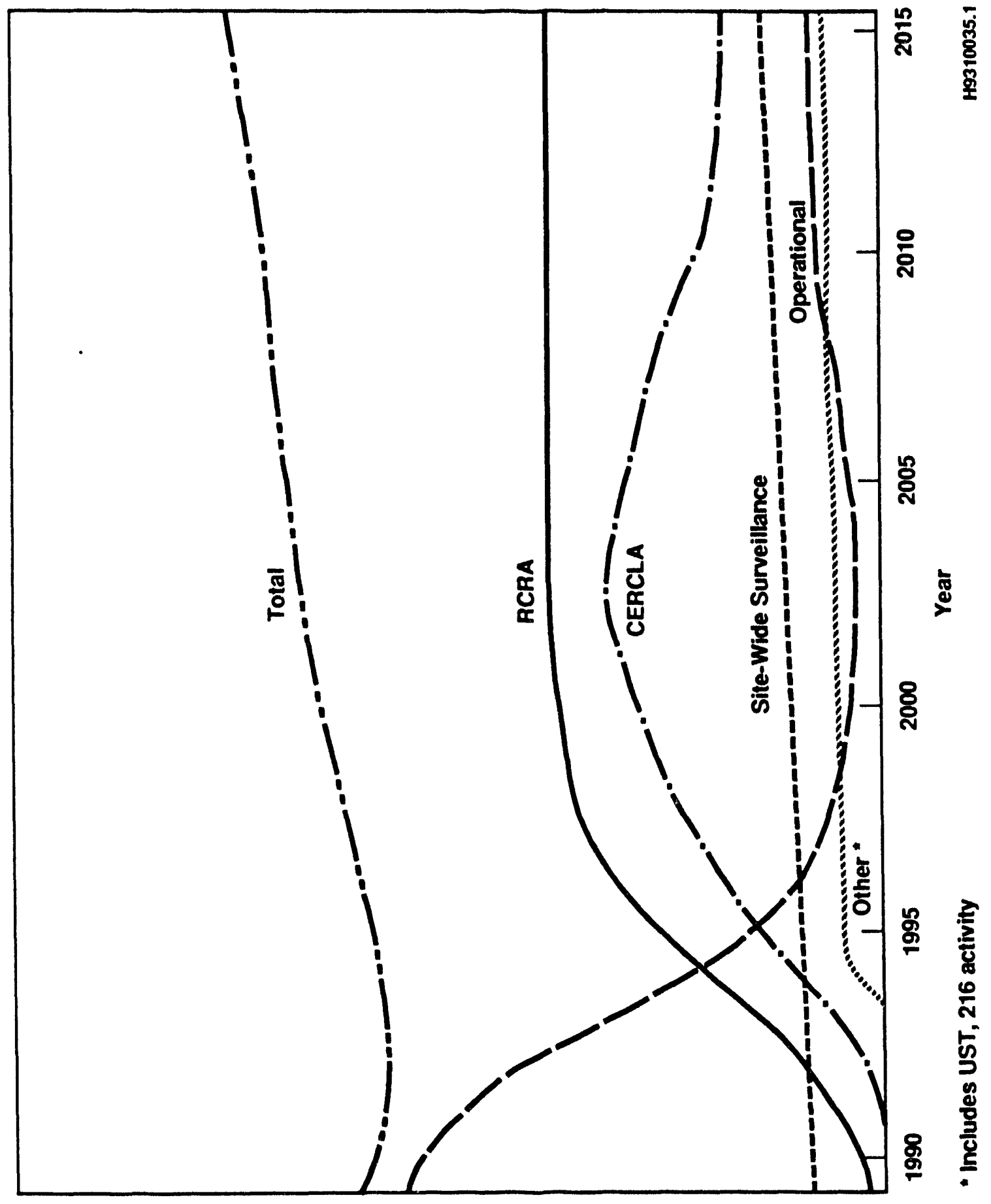

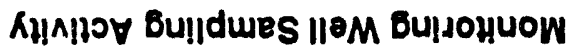


Environmental surveillance is conducted to monitor any effects of DOE activities upon the environmental and natural resources at the Hanford Site and adjoining areas. DOE Order 5400.1 (DOE 1988) requires an environmental surveillance screening program be undertaken at DOE sites to determine the need for a permanent surveillance system. The environmental surveillance program is designed to satisfy the following program objectives.

- Verify compliance with applicable environmental laws and regulations.

- Verify compliance with environmental commitments made in EISs, environmental assessments, safety analysis reports, or other official DOE documents.

- Characterize and define trends in the physical, chemical, and biological condition of environmental media.

- Establish baselines of environmental quality.

- Provide a continuing assessment of pollution abatement programs.

- Identify and quantify new or existing environmental quality problems.

The strategy for the environmental surveillance program is as follows.

- Review applicable environmental laws, regulations, and DOE orders to determine program requirements.

- Conduct a groundwater sampling, analysis, and interpretation program that will meet environmental surveillance requirements.

- Review groundwater monitoring programs conducted to meet other monitoring needs (e.g., operational monitoring, monitoring for compliance with RCRA and CERCLA regulations) on the Hanford Site and in the surrounding area.

- Identify additional data collection and analysis needed to meet environmental surveillance requirements.

Use of data gathered by other programs will allow the environmental surveillance program to meet the requirements set forth in the DOE orders in a cost-effective way.

At the present time, approximately 800 monitoring wells on the Hanford Site are used to assess the impact of specific facilities and to track the movement of contaminant plumes from past disposal practices. Many of the wells used in this assessment are selected from the operational monitoring networks to define sitewide distribution patterns of chemical and radiological contaminants. 


\subsubsection{RCRA Groundwater Monitoring}

The RCRA groundwater monitoring program currently involves site-specific monitoring and/or well installation at 20 facilities (including the Hanford Site Solid Waste Landfill). Over 250 new RCRA-compliarit monitoring wells have been installed for this purpose since 1987. Groundwater monitoring networks for several additional facilities have been prioritized and scheduled in the overall plan for meeting RCRA permitting needs at the Hanford Site. This plan has been incorporated in the Tri-Party Agreement action plan schedule. A key issue for the groundwater monitoring portion involves distinguishing pastpractice, multiple-source contaminant plumes from RCRA site-specific contaminants. Recent negotiations with regulators to expedite and streaml ine CERCLA investigations should help resolve these problems.

Implementation of RCRA at the Hanford Site involves preparation of groundwater compliance monitoring plans for each regulated unit (identified and prioritized in the action plan). The plans include specifications for well location, construction, hydrogeologic characterization, sampling and analysis, and parameters dictated by the groundwater protection plan outlined in WAC 173-303 and 40 CFR 265, Subpart F. The focus of these plans is on detection and assessment monitoring at the waste source or waste management area boundary. The intent of these requirements is to determine if groundwater contamination has occurred from these facilities and what, if any, corrective action may be indicated. A detailed listing of these plans is included in the groundwater monitoring plans summary document, updated annually (see Figure 1-1).

The overall process involved in implementing the RCRA groundwater protection provisions of 40 CFR 265 and 40 CFR 264 is summarized in Figure 5-2. The GPMP provides direction to the six major groundwater protection programs, each of which interacts with the RCRA groundwater program. Coordination among these programs is effected through WHC functional organizations, such as the Well Administrator Team (see Section 5.4.1) and integrated organizations such as the Geohydrologic Working Group (GWG). Information needs are derived from the permitting process and hydrogeologic requirements identified in the six subtier plans. The middle of the diagram illustrates the flow of information needed to comply with RCRA-related groundwater requirements and WHC procedural requirements. The lower portion of the diagram illustrates the interrelationship of activities leading to the final output as quarterly and annual monitoring reports and characterization data for permit-related documents (i.e., RCRA closure and postclosure plans).

\subsubsection{Operational Monitoring}

Operational groundwater monitoring has been carried out at the Hanford Site since the early days of site activity. The initial objective of this monitoring was to evaluate the impact of disposal operations on the environment, with the specific objective of determining when it was necessary to replace a soil column disposal facility. Historically, the operational monitoring program has been directed toward radionuclide monitoring, although 
Figure 5-2. Hanford Site RCRA Groundwater Program Process Flowsheet.

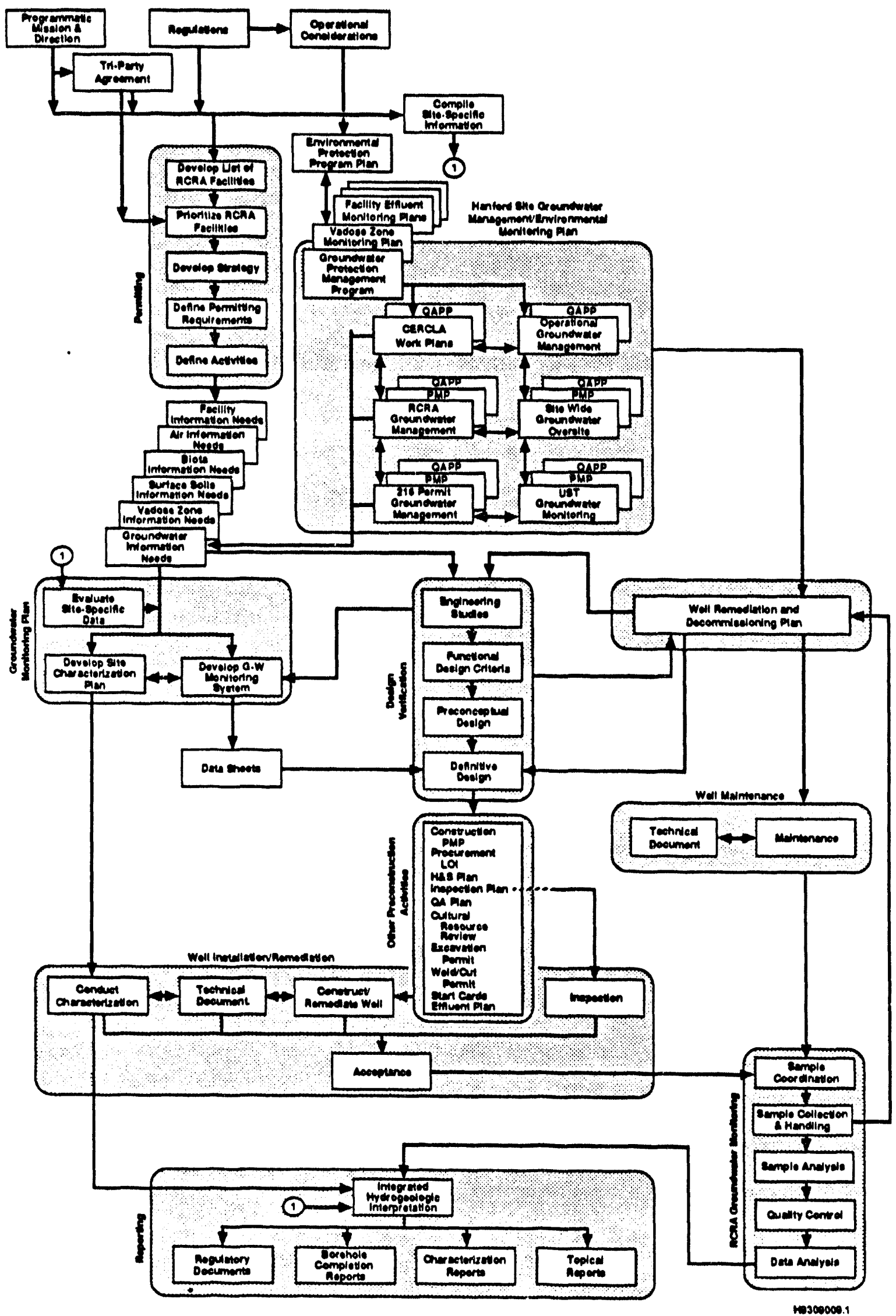


attention was given to nitrate because of its widespread use and mobility in groundwater. Monitoring for hazardous chemicals has been phased into the program over the past several years. Approximately 300 wells are used for operational groundwater monitoring (Johnson 1993).

Operational monitoring, which may be considered "near-field" monitoring, addresses groundwater conditions in and adjacent to reactor and chemical processing operations in the 100,200,300,400, and 1100 Areas. Sitewide surveillance monitoring provides more widespread coverage than operational monitoring, but al so allows independent evaluation of operational groundwater monitoring results.

Currently, the operational program serves as a mechanism for the integrating and reporting of groundwater-related activities originating within other programs (RCRA, CERCLA, 216, etc.) on the Hanford Site. Geological, geochemtcal, and hydrological information is continually compiled and presented annually in the Westinghouse Hanford Company Operation Groundwater Status Report (WHC 1993b). Ongoing objectives of the operational groundwater monitoring program include:

- Identify sources of groundwater contamination and maintain surveiliance of these sources

- Establish baseline conditions of groundwater quality and quantity

- Evaluate impact of disposal operations on the groundwater flow system

- Determine if active disposal facilities are causing contamination of the groundwater above standards

- Provide capability for early detection of leakage from inactive disposal facilities contaminating the groundwater

- Identify and track existing contaminant plumes

- Demonstrate compliance with all applicable regulations and DOE orders

- Coordinate with RCRA, CERCLA, and other monitoring to avoid gaps and duplication in data coverage

- Keep WHC management and DOE informed on the status of the groundwater in the operating areas

- Provide a technical basis for decision making relative to disposal practices and the management/protection of groundwater

- Conduct the program in a cost-effective manner. 
Strategies for meeting the requirements of operational groundwater monitoring are:

- Maintain knowledge of existing federal and state regulations and DOE orders

- Monitor water levels of aquifers to determine directions of flow and hydraulic gradients for estimation of near-field dispersal rates and directions

- Select existing wells or identify need for new wells for monitoring active/inactive disposal facilities in operating areas in coordination with RCRA, CERCLA, and surveillance monitoring

- Review operating history of inactive facilities and effluent characteristics of active facilities

- Develop sampling/analysis plan for operational monitoring network in coordination with RCRA and CERCLA monitoring. Assess

appropriateness of regulatory lists (WAC 173-303-9905, "Dangerous Waste Constituents List," WAC 173-360, "Underground Storage Tank Regulations," WAC 173-216, "State Waste Discharge Permit Program," and 40 CFR 264, Appendix IX) for inclusion in operational monitoring

- Oversee sample collection, analysis, and interpretation of analytical results

- Identify trends associated with individual wells and track the formation and movement of contaminant plumes

- Provide groundwater information to management in the form of notes, reports, and/or presentations

- Integrate monitoring information with that obtained by hydrologic characterization and flow/transport modeling to provide technical basis for decision making

- Coordinate all activities with RCRA, CERCLA, 216 Permit, and UST monitoring and PNL sitewide groundwater surveillance

- Maintain an awareness of costs and seek improved methods of operation to reduce costs while maintaining or enhancing the integrity of the program.

Sampling frequencies, locations, and parameters are based on operational needs and are updated at least annualiy in the operational groundwater monitoring plan.

The flowsheet for the operatior: 17 program is shown in Figure 5-3. Output is in the form of technical reports and quarterly and annual monitoring reports to demonstrate compliance with DOE and WHC administrative limits. However, as discussed earlier, the operational groundwater program is in a transitional phase as RCRA and CERCLA programs progress. 
Figure 5-3. Hanford Site Operational Groundwater Program Process Flowsheet. (2 sheets)

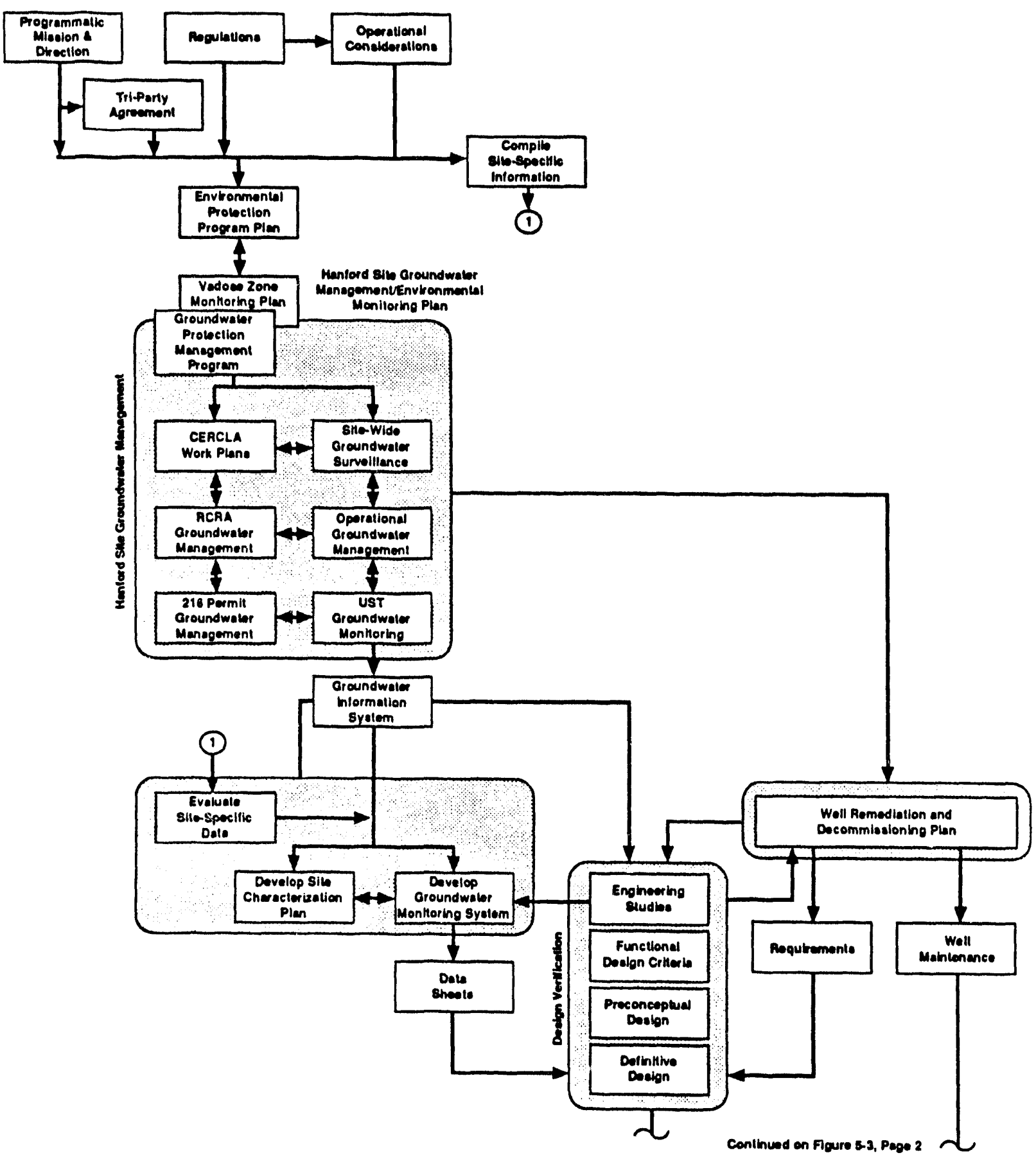

H02 10010.3 
Figure 5-3. Hanford Site Operational Groundwater Program Process Flowsheet. (2 sheets)

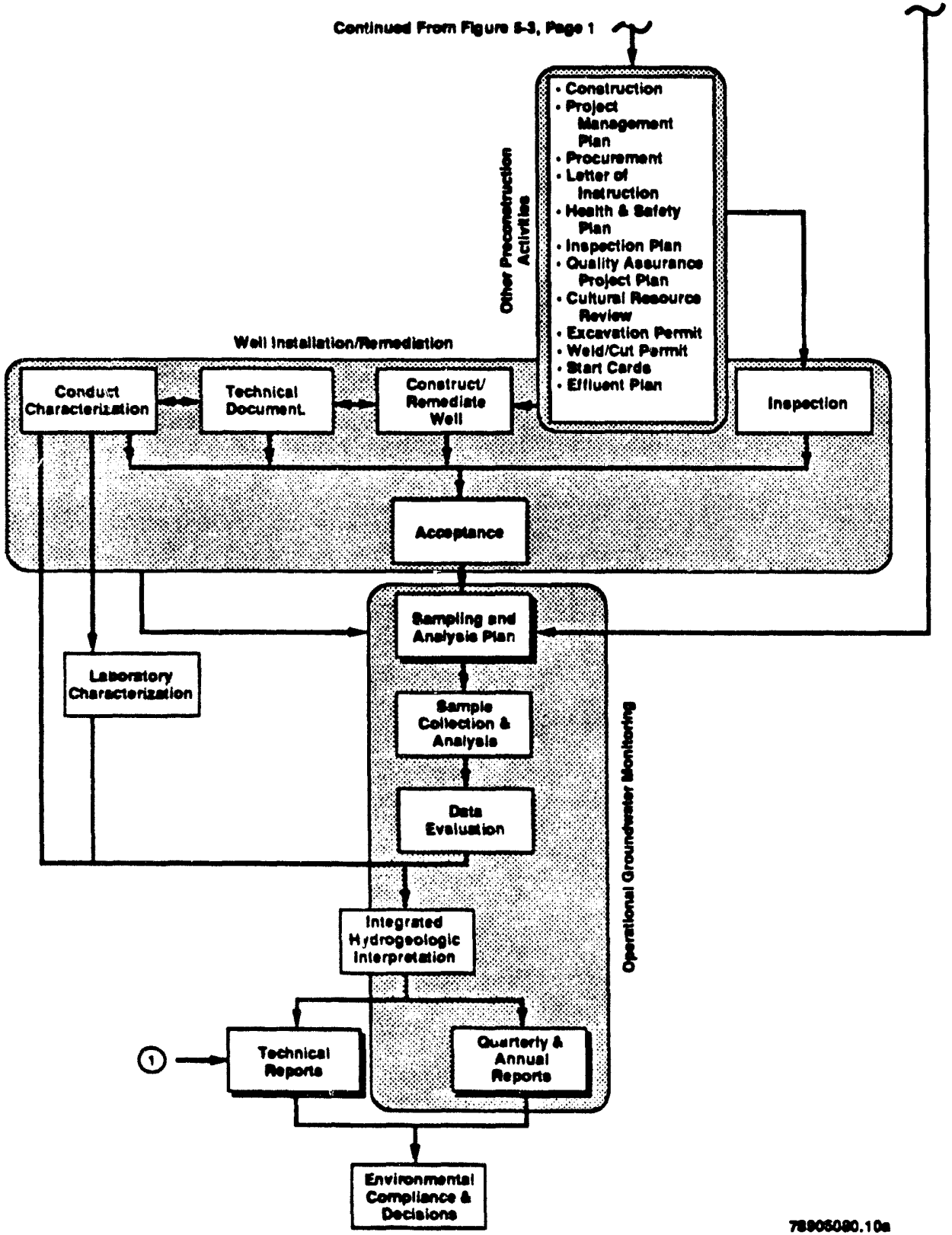




\subsubsection{Groundwater Characterization Under CERCLA}

A strategy for CERCLA actions at the Hanford site is illustrated in Figure 5-4. Groundwater monitoring and related site characterization for operable units (groupings of regulated units) are treated separately to allow for the difference between the more localized contaminants in the soil column at the sources and the more widespread distribution of groundwater contaminant plumes that may result from one or more individual sources. The concept of the groundwater operable unit has been adopted to separate characterization of the specific waste site or unit from groundwater characterization. Monitoring wells are located so as to define the nature and extent of the contaminant plume, rather than tightly grouped at the individual waste source as for RCRA sites. Groundwater operable units are described in Appendix D of the Tri-Party Agreement.

The CERCLA process (Figure 5-5) is similar to the RCRA process described, except the permitting function is replaced by project scoping and a sitespecific work plan function that specifies data needs as coordinated through the GPMP and the Hanford Site Groundwater Management/Environmental Monitoring Plan. Another important difference between the RCRA and CERCLA activities at the Hanford Site is the mechanism of program implementation. For example, CERCLA work is often conducted by subcontractors with overall project management controlled by DOE and the prime contractor (WHC); whereas, the RCRA groundwater program is usually conducted by the operating contractor (also WHC) for the facilities involved. The final CERCLA output is in the form of technical reports and remedial investigation reports that are used to support feasibility studies for remediation.

\subsubsection{Waste Discharge Permit Program}

In December 1991, Ecology and DOE signed Consent Order No. DE 91NM-177, al so known as the Liquid Effiuent Consent Order (Ecology and DOE 1992). Under this order, permits administered by WAC 173-216, "State Waste Discharge Permit Program" (SWDP or 216 Permit) or National Pollution Discharge El imination System (NPDES), are required for certain liquid waste streams. The order also affects the practice of discharging liquid effluents to the ground at the Hanford Site. This order is distinct from, though consistent with, the Tri-Party Agreement.

Two key provisions of the Liquid Effluent Consent Order are:

- DOE agrees to abide by all applicable state water quality criteria (e.g., WAC 173-200 and 173-201), provided those criteria are consistent with Ecology's statutory authority and are applied on a nondiscriminatory basis statewide.

- DOE agrees to secure permits for effluent streams discharged at the Hanford Site, as required by applicable law. 


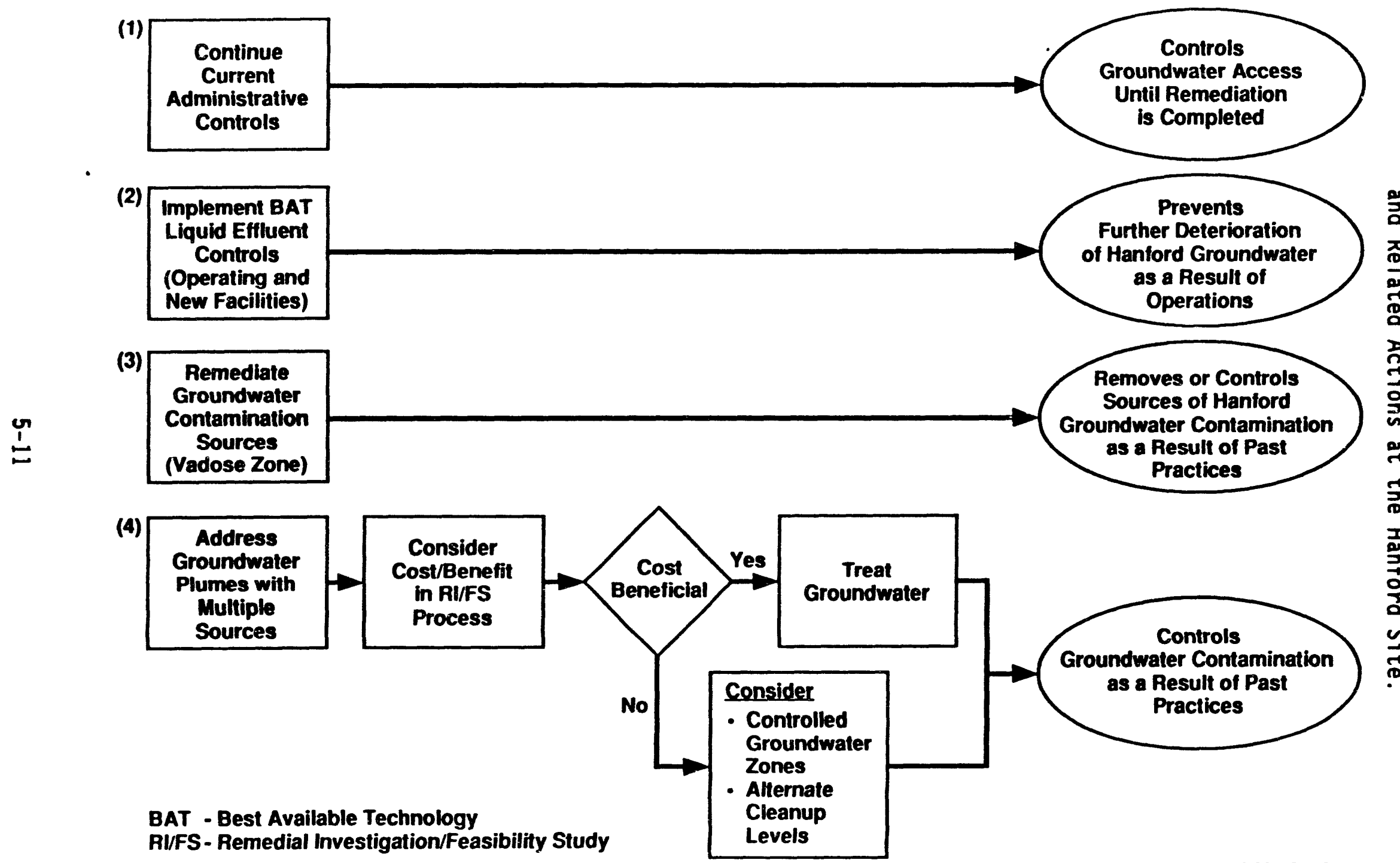

BAT - Best Available Technology

RI/FS - Remedial Investigation/Feasibility Study 
Figure 5-5. Hanford Site CERCLA Groundwater Program Process Flowsheet. (2 sheets)

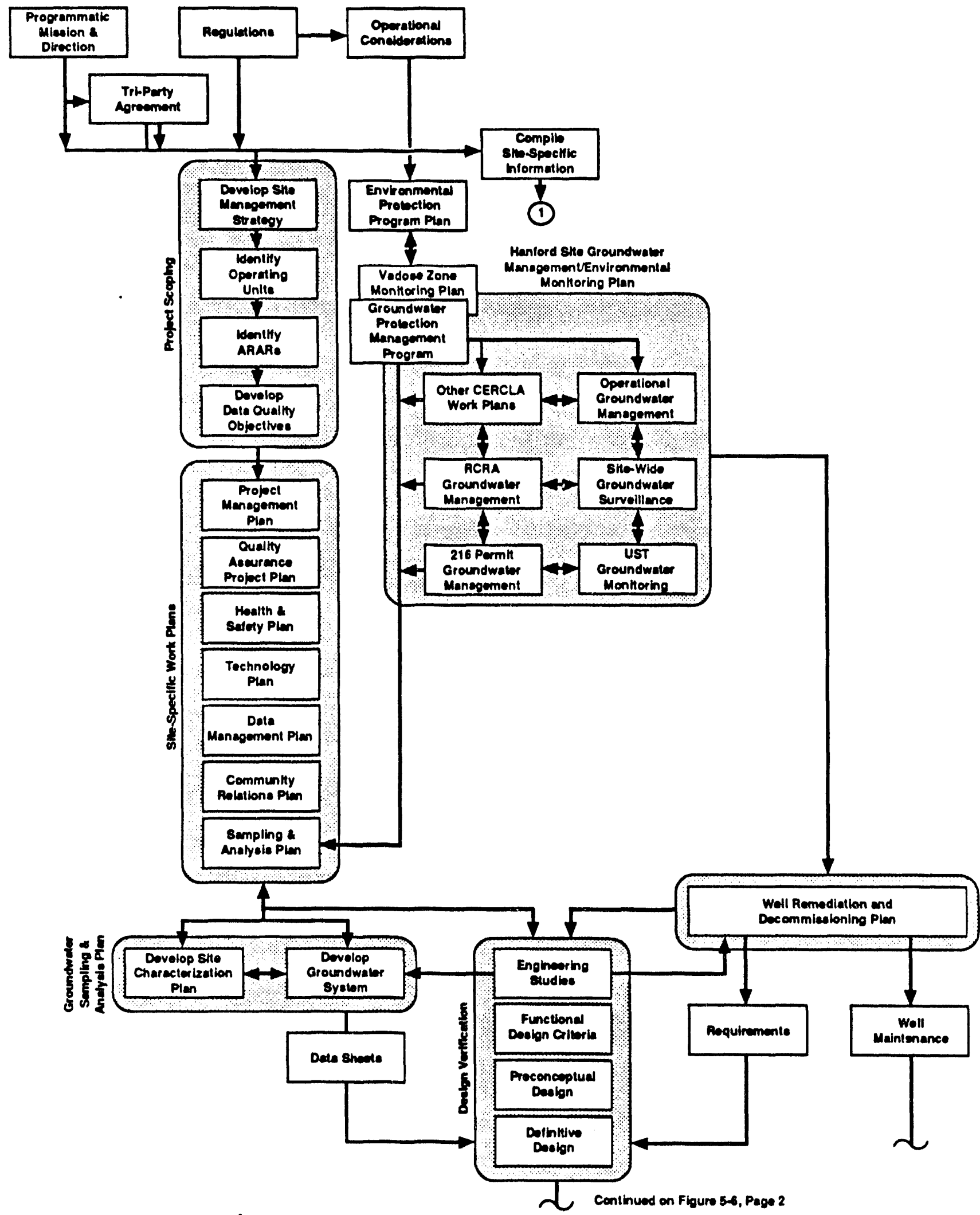

$H 92100052$ 
Figure 5-5. Hanford Site CERCLA Groundwater Program Process Flowsheet. (2 sheets)

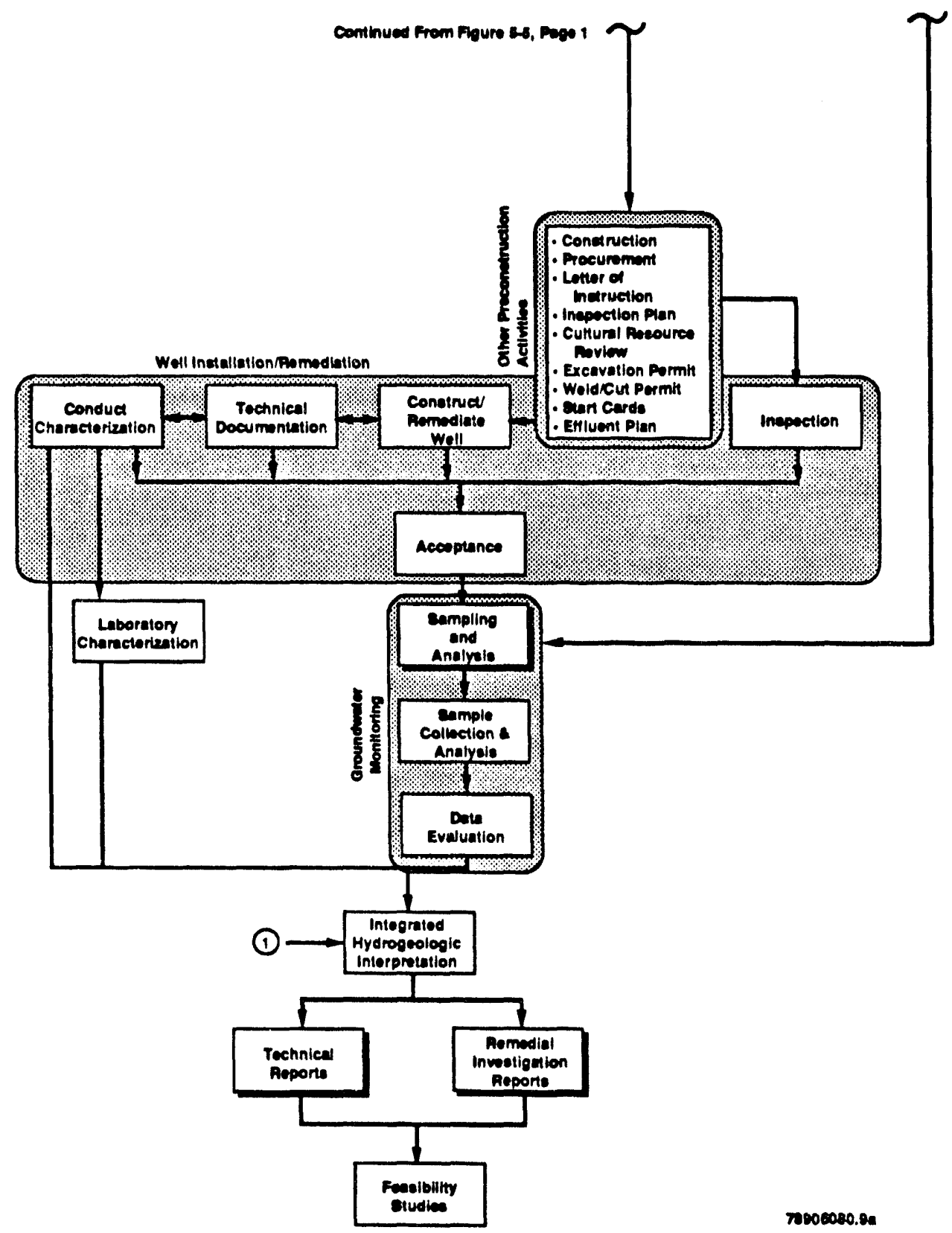


A 216 Permit requires submittal of an engineering report of Best Available Technology or All Known and Reasonable Technology (BAT/AKART) (WAC 173-204-130). The engineering report must include a geohydrologic evaluation of the liquid effluent receiving site. Also sampling and analysis plans are required for 1 iquid effluents, and groundwater impact assessments are required for some specific disposal sites.

Related to the 216 Permit program are monitoring requirements attendant to Tri-Party Agreement Milestone M-17-00, "Complete liquid effluent treatment facilities/upgrades for all Phase I streams." Under this milestone, disposal to the soil column of all untreated effluents will cease as of June 1995. Treated Effluent Disposal Basins receiving treated effluents will incorporate groundwater monitoring required by the 216 Permit program as part of their operation.

\subsubsection{Underground Storage Tanks Program}

In October 1991, Ecology finalized "Underground Storage Tank Regulations" (WAC 173-360), which controls the underground storage of petroleum products and "other regulated substances." However, radioactive, hazardous (subject to Subtitle $C$ of the federal Solid Waste Disposal Act of 1974) and mixed waste are exempt from these regulations. Sections $345(6)(\mathrm{g})$ and 520 of WAC 173-360 set provisions for groundwater monitoring in conjunction with USTs. Recent agreements between DOE and Ecology have acknowledged this state code as the underlying authority for groundwater monitoring and other applicable activities concerning USTS.

\subsubsection{Support Needs}

The groundwater surveillance, characterization, and monitoring programs described above are dependent on reliable sampling and analysis methods and collection of critical data to support cleanup/closure decisions or demonstrate compliance. The sampling and analysis results are in turn dependent on proper well installation, adequate well development ("cleanup pumping" before sampling), sampling equipment, and site-specific sediment and hydrochemical data.

With the increasing number of groundwater monitoring wells drilled, the disposing of potentially contaminated purge water was soon recognized as a major issue. In October 1990, Ecology, EPA, and DOE reached an agreement regarding the strategy for handling and disposing of these waters (WHC 1990). This agreement provides procedures and criteria for disposal of waters extracted from monitoring wells during sampling, maintenance, testing, and development. 


\subsubsection{Subsurface Data Collection Criteria}

Some general criteria are common to all activities requiring subsurface measurements. To ensure maximum use is made of each borehole (to support performance assessment needs as well as monitoring activities), the following guidelines are adopted.

- Monitoring well locations are selected using all available groundwater data, local hydraulic gradient information, source locations, and waste characteristics. Plume modeling is applied to determine an appropriate array of initial well locations.

- The probability of encountering contaminants with densities greater than water (e.g., dense, nonaqueous-phase liquids) is evaluated. For example, carbon tetrachloride is known to occur widely in the subsurface within and near the 200 West Area of the Hanford Site. Vertical distribution of contaminants will, in part, govern well design.

- In addition to Contamination Indicator Parameters and water quality parameters, site-specific indicators are chosen based on the records of waste composition for waste sites likely to have contributed to vadose zone or groundwater contamination. Other groundwater sampling requirements are as directed in WAC 173-303-645. Chemical characterization of the groundwater should also include an assessment of the possible presence of colloidal phases and basic geochemical characteristics ( $\mathrm{pH}$, redox, major ion composition) for geochemical modeling predictions of contaminant stability.

- It will be necessary at many waste sites to demonstrate compliance with long-term groundwater protection standards (RCRA). This will require knowledge about the lithology beneath the waste site and reactivity of the contaminants with the sediments. Thus, sediment samples are acquired during the drilling of every monitoring well for possible analysis.

\subsection{VADOSE ZONE CHARACTERIZATION AND MONITORING}

The vadose zone (unsaturated soil and sedimentary deposits above the water table) contains the radioactive/hazardous mixed waste of concern as a potential source of contaminants to groundwater at the Hanford Site. The depth distribution of contaminants from releases, discharges, and leaks is of primary concern to operational programs and remedial investigations for RCRA/CERCLA activities. Primary areas of interest are: (1) the recharge or infiltration rates at waste sites (the driving force for downward movement of contaminants), (2) physical and chemical characteristics of the sediment/soil column, which, along with recharge is needed for predicting contaminant mobility and calculation of el:gineered barrier design/performance requirements, and (3) vadose zone monitoring of subsurface waste storage and disposal sites to provide early warning of waste movement that could potentially cause future groundwater contamination problems. 


\subsubsection{Net Infiltration}

The net infiltration of precipitation is dependent on climate and soil/ sediment texture. These variables are being evaluated experimentally and with transport models at the Hanford Site in connection with the performance assessment and engineered barriers programs. Because compliance with groundwater protection standards will be based on performance assessment models, model validation is of particular concern to the GPMP. This information is critical to demonstrate with "reasonable assurance" that infiltration rates, the most important variable in contaminant transport models, are credible for Hanford Site conditions.

Near-term validation plans include the use of old spill sites as "tracer experiments" to gain greater confidence in short-term (months), small-scale collection lysimeter results. The change in contaminant depth-distribution over tens of years will be evaluated at suitable waste sites for this purpose (Routson and Johnson 1988). Natural analogs such as the caliche layers in many soil profiles at the Hanford Site are also being evaluated as long-term indicators of net infiltration (during the past 10,000 years).

\subsubsection{Contaminant Mobility and Engineered Barriers}

Engineered barriers at the Hanford Site represent long-term groundwater protection measures (see Section 4.5). These structures have been under development for several years (Adams and Wing 1986; DOE 1987) at the Hanford Site and are intended to minimize human and biological intrusion, erosion, release of noxious gases from waste zones, and to inhibit the infiltration of moisture (Figures 5-6 and 5-7).

As discussed in Section 4.5, a groundwater protection, drinking water standard may be used as a design performance standard for barriers in the revised 40 CFR 191 rule governing HLW and TRU radioactive waste disposal. In-place stabilization options that rely on waste form/barrier must demonstrate compliance (over a 1,000-year period) with the dose equivalent drinking water standard of $4 \mathrm{mrem} / \mathrm{yr}$ (including background). Other input data requirements are waste composition, chemical properties and spatial variability of vadose zone sediments, waste reactivity with vadose zone sediments, and net infiltration capacity and physical properties of the soil column. With appropriate performance assessment models and reasonable input data, the infiltration rate that will maintain groundwater concentrations below the drinking water standard over 1,000 years can be calculated.

The Barrier Development Program has been in existence since fiscal year (FY) 1986. Since then, the emphasis of the program's efforts has been on the development and testing of various barrier components. For the most part, these development and testing efforts have been performed either in the laboratory or on relatively small-scale field plots. Although not completely resolved, issues pertaining to protective barrier performance with respect to water infiltration, biointrusion, erosion and deposition, human interference, physical stability, and climate change are being addressed. During FY 1992, a full-scale prototype barrier was designed. This prototype is planned for construction in FY 1994. The design and construction of a prototype barrier forces all of the various components of the barrier to be brought together 
Figure 5-6. Engineered Barrier Functional Performance.
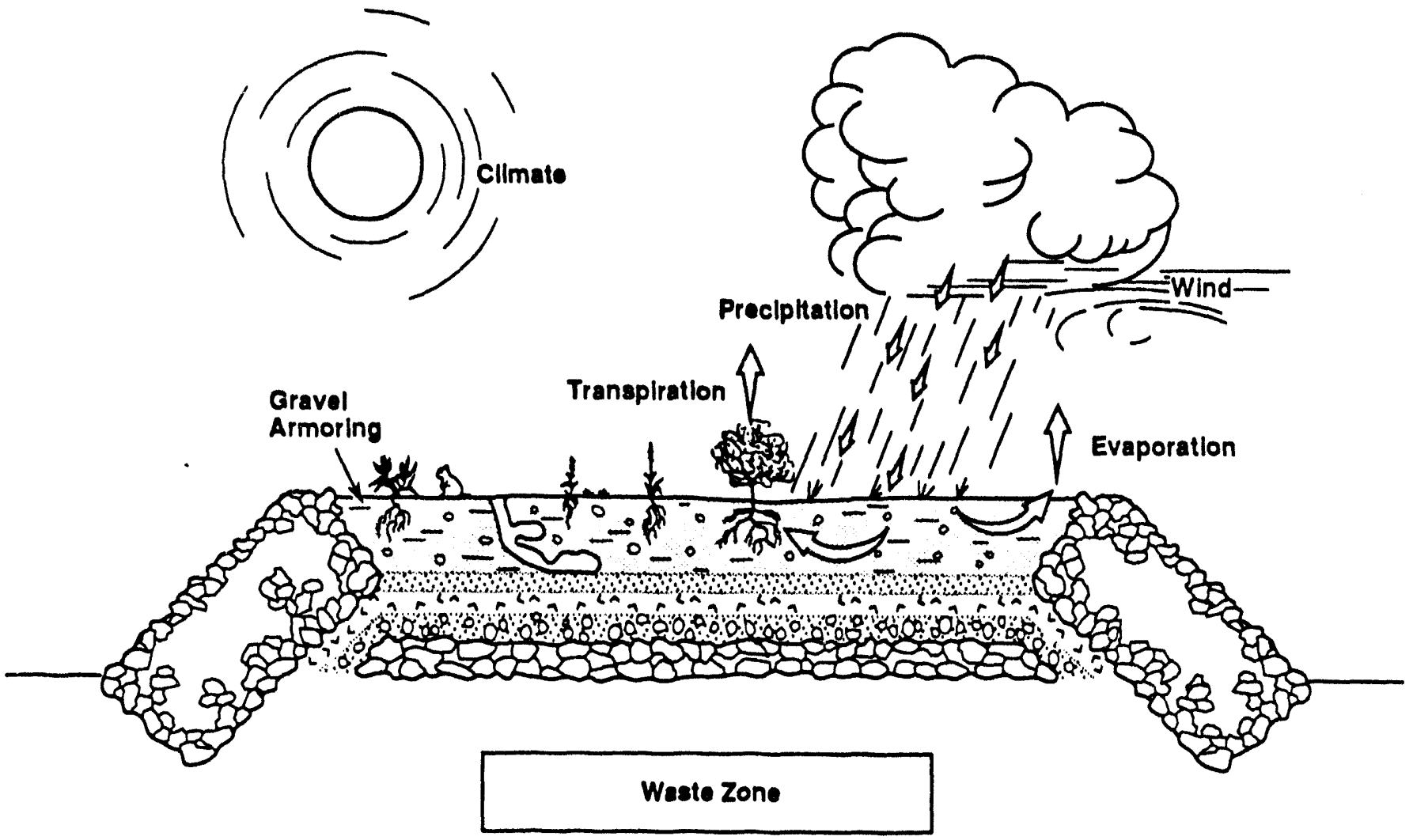

Figure 5-7. Engineered Barrier Development. Tasks.

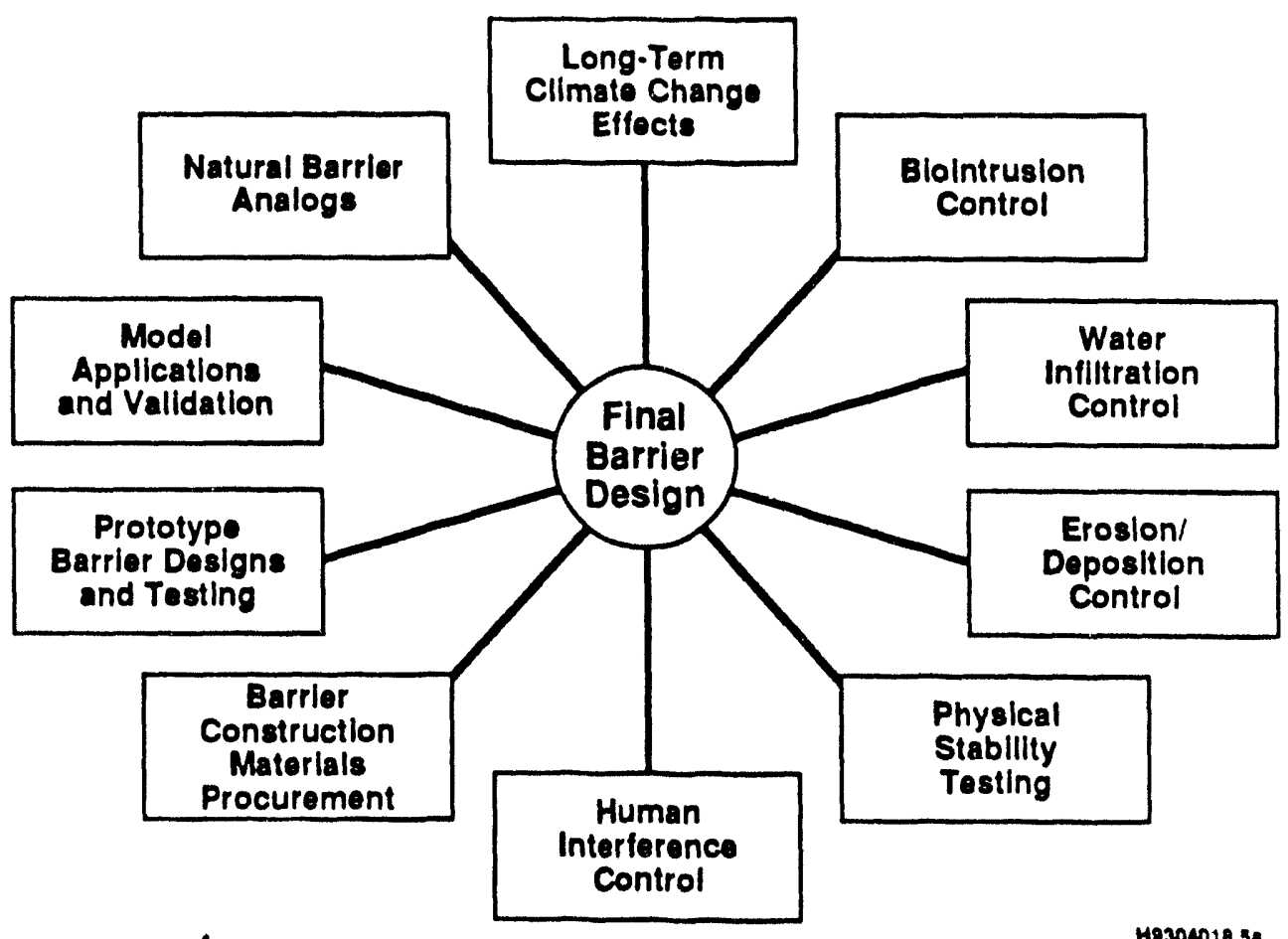


into an integrated system. This integration is particularly important because some of the components of the protective barrier have had to be developed independently of other barrier components. The prototype will also provide engineers and scientists with a capability for testing the performance of a full-scale barrier, something that has not been possible with the relatively small-scale tests and experiments that have been conducted to date in the program. The Barrier Development Program is expected to be completed in the late 1990 's.

Some of the information for the above purposes is being acquired in connection with the Barrier Development and Performance Assessment Programs. Background radionuclide concentrations are in part avallable from groundwater monitoring activities and past repository studies. Additional information is acquired through special sampling and characterization efforts.

To predict contaminant movement via performance assessment modeling, information in addition to contaminant concentrations is required. Soils are characterized and archived, to the extent possible, to maximize understanding of variability of chemical and physical properties of soils that control contaminant transport. By collecting and archiving as much of the soil column as possible during the drilling of monitoring wells, samples will be available for characterization and later use in laboratory evaluation. To advance this strategy, the Hanford Site Background: Part 1, Soil Background for Nonradioactive Analytes (DOE-RL 1993) was completed in early FY 1993. Likewise, groundwater quality background studies are presented in Hanford site Groundwater Background (DOE-RL 1992b).

\subsubsection{Vadose Zone Monitoring Strategy}

Radionuclides and hazardous waste were discharged or placed in various cribs, ponds, ditches, and burial grounds at the Hanford site. When effluent is discharged from impoundment or infiltration facilities into the surrounding sediment, the radionuclides and hazardous constituents that precipitate out of solution, are adsorbed on the sediment or, in the case of highly mobile species, slowly migrate both horizontally and downward. The greatest portion of these hazardous constituents is retained within the unsaturated zone (vadose zone) above the unconfined aquifer.

There are two main objectives to this program: (1) to protect the groundwater from contamination (short term) and (2) to provide contaminant characterization and migration information for performance assessment modeling (long-term groundwater protection assessment).

Monitoring to protect the groundwater is particularly important for active facilities where large volumes of effluent can be expected until discharge to the soil column is eliminated in 1995. Vadose zone characterization and monitoring are essential activities required to support the Hanford Site defense waste EIS (DOE 1987). Vadose zone monitoring is also required to satisfy data needs for performance assessment modeling for the waste sites. These models require data on the concentration and location of contaminants over long periods of time (several years), and will be used to confirm computer modeling of specific contaminant migration. 
Vadose zone monitoring will determine the concentrations, area/ distribution and movement of radionuclides, and nonradioactive hazardous constituents retained within the vadose zone. Initially, the focus will be mostly on the gamma-emitting component of the radioactive waste. This monitoring is required by DOE Order 5820.2A, Radioactive Waste Management (DOE 1984). The plan is al so required to provide data for performance assessment modeling needed to satisfy the requirements of RCRA, CERCLA, and to address comments received from Ecology in a Notice of Deficiency in 1990 on the Single-Shell Tank (SST) Closure/Corrective Action Work Plan. Improvements to vadose zone monitoring will also respond to concerns of reports of the General Accounting Office and the DOE Tiger Team regarding the fate of waste leaked to the solls from the SSTs. A joint Cooperative Research and Development Agreement between PNL and WHC has been approved. The Cooperative Research and Development Agreement will adapt commercial geophysical logging techniques to the Hanford Site using two commerctal logging companies.

5.2.3.1 Radionuclide Monitoring Techniques. Radionuclide monitoring at active and inactive waste sites will be accomplished with a combination of borehole geophysical logging techniques. Existing and new wells provide access to the contaminated zones. Logging probes will be lowered into these wells to measure responses that can be used to interpret the radionuclide concentration and distribution as well as the sediment moisture profile. Soil moisture will be monitored because water is the main driving mechanism for the migration of radionuclides and hazardous waste. Logs are analyzed and archived for comparison at a later date. Log data are supplemented with actual sampling, where needed, to measure the concentration of radionuclides more accurately.

5.2.3.2 Hazardous Chemical Monitoring. Hazardous, nonradioactive contaminants are more difficult to monitor than the radioactive contaminants. This type of monitoring will employ a combination of soil gas sampling and analysis and actual sediment sampling. Because of the expense of drilling and sampling, it is expected that hazardous chemical monitoring will be more of a characterization effort as opposed to a regular monitoring task.

5.2.3.3 General Monitoring Plan. A vadose zone monitoring strategy is now in preparation by WHC. The plan will identify monitoring requirements, monitoring technology, the requirements of the various monitoring methods, monitoring frequencies, site priorities, and monitoring well criteria. This plan will establish the basis for monitoring and provide guidelines for preparation of site-specific monitoring plans and Data Quality objectives.

5.2.3.4 Site-Specific Monitoring Plans. Because each waste site is unique (i.e., site geometry, geology, hydrology, and waste constituents), sitespecific vadose zone monitoring plans will be required. For isolated, inactive sites with relatively innocuous contaminants, a monitoring frequency of once every 5 years may be adequate. All untreated liquid effluent discharges to soils will cease by June 1995, at which time monitoring will change to satisfy the Data Quality Objectives for design, testing, and assessment of environmental restoration. 


\subsection{PASCO BASIN CONCEPTUAL HYDROLOGIC MODEL}

Management of groundwater resources requires a conceptual model of surface water and groundwater regimes on a basinwide scale. Figure 5-8 is a simplified version of such a conceptual model for the Hanford site. The strategy for the cont inued development of conceptual and numerical models involves collection and analysis of the following types of information:

- Geohydrologic framework (stratigraphic and structural relationships, hydrostratigraphic units, etc.)

- Hydrochemical facies

- Physical parameters of aquifers (hydraulic conductivity, head distributions, flow dynamics, volumetric flow rates, net infiltration, etc.)

- Recharge/discharge boundaries (both natural and artificial).

This information is used to assess groundwater movement, surface water/ groundwater interactions, and to evaluate manmade surface and subsurface perturbations on the system (wastewater discharge, irrigation withdrawals, etc.).

Much information is avallable as a result of past defense waste and nuclear repository characterization studies and ongoing studies conducted by state and federal natural resource agencies. A significant portion of the data acquisition and model development has been documented in site characterization reports and plans (DOE 1987; DOE-RL 1988). These documents also provide detailed descriptions of additional data requirements that will be used as guidance (where applicable to surface water/groundwater interactions and evaluation of the unconfined and uppermost confined aquifer systems). Hydrologic models to assess contaminant transport in the vadose zone and in groundwater have been developed and are used and upgraded as needed.

Existing data acquisition plans to define the hydrologic regimes within the Pasco Basin are still valid and are taken into consideration when defining and prioritizing future data needs to support current basinwide characterization efforts. Current plans focus on acquiring critical groundwater protection/management information that includes, but is not iimited to, the following.

- Recharge data to better quantify groundwater transport in the unconfined aquifer (the aquifer beneath the Hanford Site most vulnerable to contamination).

- Effects of agricultural recharge (i.e., impact of Columbia River Irrigation Project activities) on confined-system flow dynamics beneath the Hanford Site. 
Figure 5-8. Major Surface Water Features of the Pasco Basin that Influence the Groundwater Regime Beneath the Hanford Site.

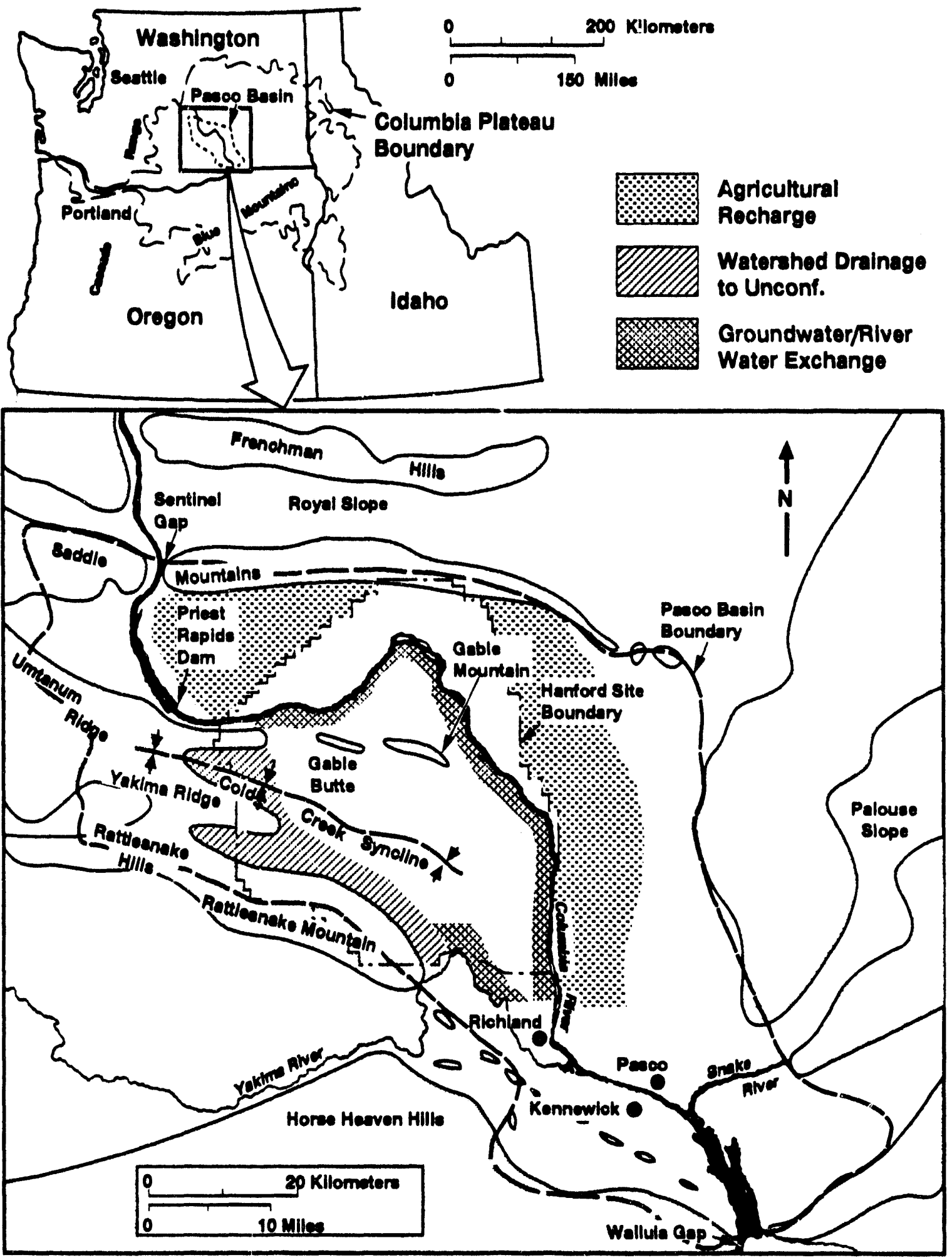

Kust1011.1 
- Interconnectivity and potential for groundwater exchange between unconfined and confined aquifers.

- Intercommunication and exchange between the Columbia River and the unconfined aquifer (100 Areas).

Opportunities for cooperative research efforts involving DOE contractors, universities, and the U.S. Geological survey are routinely sought to ensure coordination with related programs underway in the region, and to avoid duplication of efforts.

\subsection{INTEGRATION OF PROGRAMS}

The various programs involving groundwater-related information needs must be effectively coordinated to: (1) avoid duplication of efforts, (2) minimize costs, (3) avoid inadvertent conflicts, (4) maximize use of boreholes and wells, (5) ensure the timely acquisition of critical information, and (6) complete mission objectives. Strategy elements to address these objectives include, but are not limited to, the following.

- A centralized database management system to facilitate dissemination and storage of existing and future data.

- The Well Administrator Team is established to coordinate locating, use and well maintenance, and well ownership (for activity funding purposes).

- The GWG of onsite and offsite peers is established to periodically review sitewide groundwater-related data and needs, and to make recommendations for improving groundwater resource management at the Hanford Site.

Organizational and administrative aspects of the above are discussed in the Environmental Protection Implementation Plan (DOE-RL 1992a). Conceptual and technical aspects are discussed in the following sections.

\subsubsection{Nell Administrator Team}

The Well Administrator Team is a multilateral organizational element with a central role in monitoring well oversight. Regular participants in bimonthly meetings and the Well Administrator Team efforts include RL, WHC, PNL, Washington Public Power Supply System, and the U.S. Army Corps of Engineers.

Currently, over 3,000 vadose zone and groundwater monitoring wells exist on the Hanford Site (Chamness and Merz 1993). Many new monitoring wells (roughly 300) meeting regulatory standards have been drilled since 1987. Additional new wells may be needed to meet regulatory requirements for CERCLA, RCRA, and operable unit groundwater monitoring. Most older monitoring wells were installed for either operational purposes or for the sitewide environmental surveillance program conducted by PNL. Some of the older wells 
meet specifications, but most require replacement or modification for meeting new standards. Many wells that are beginning to go dry, because of reduced effluent discharge and lowering water tables, may also be modified, abandoned, or replaced.

WHC (Environmental Field Services) is functionally responsible for the management, field direction, and documentation of groundwater well remediation on the Hanford Site. Straiegy for well remediation and decommissioning activities is described in the Hanford Well Remediation and Decommissioning Plan (WHC 1993a).

\subsubsection{Geohydrologic Working Group}

To provide a broad perspective and maximize hydrogeologic information acquisition, senior technical staff representatives from organizations involved in Hanford Site characterization studies meet periodically as the GWG. Agendas include technical exchange presentations of topics in the subject area and panel discussion of additional data needs. Outside technical experts are invited to provide independent review and assessment of program progress and direction. Recommendations for any new information needs or changes in direction are prepared by the GWG and reviewed in conjunction with the Well Administrator Team for consideration in future funding for the necessary actions.

\subsubsection{Hanford Environmental Information System}

The Hanford Environmental Information System (HEIS) is a consolidated set of automated resources that effectively manage the data gathered during environmental monitoring and restoration of the Hanford Site. The HEIS includes an integrated database that provides consistent and current data to a 11 users and promotes sharing of data by the entire user community (Figure 5-9).

Data stored in the HEIS are collected under several regulatory programs. Currently these include CERCLA, RCRA, and the Ground-Water Environmental Surveillance Project, managed by PNL.

As the title suggests, the HEIS is an information system with an inclusive database. Although the database is the nucleus of the system, the HEIS also provides user access software: menu-driven data entry, reporting, extraction, and browsing facilities; an ad hoc query facility; two-dimensional graphics; and a geographic information system.

The HEIS serves as a central repository for all groundwater data collected on the Hanford Site. Information on water levels, groundwater chemistry, sampling, and monitoring well activity and ownership are available on HEIS for incorporation into smaller, user-tailored databases. 
Figure 5-9. Hanford Environmental Information System User Community.

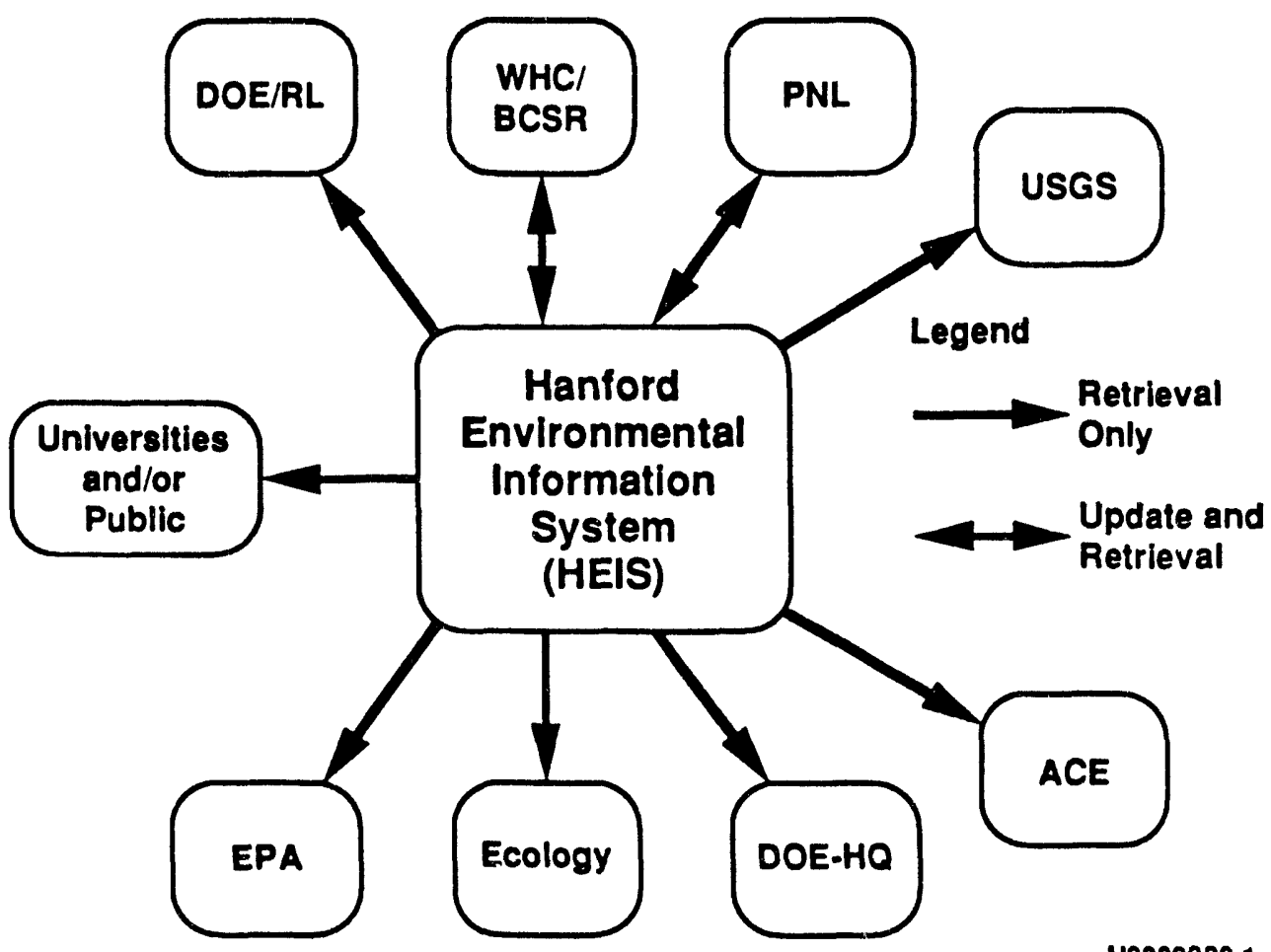

H9209022.1 


\subsection{IDENTIFICATION AND CONTROL OF HAZARDOUS HASTE SOURCES}

Section III of DOF Order 5400.1 (DOE 1988) specifies inclusion of programs dealing with identification of hazardous waste areas and strategies for controlling these potential sources of groundwater contamination. This requirement is met by existing documents such as the Hanford Site defense waste EIS (DOE 1987) and the Tri-Party Agreement. This agreement includes a detailed action plan that identifies and prioritizes waste sites for cleanup actions. The strategy for controlling waste sources as a groundwater protection measure places emphas is first on terminating liquid waste disposal to ground by 1995. This is a major near-term groundwater protection provision of the agreement. Long-term groundwater protection is addressed by removal and solidification of high-level liquid waste stored in underground tanks, and cleanup and closure of inactive waste units. Generalized prioritization and major milestones are shown in Figure 6-1. Detailed waste site priorities are listed in the master plan and schedule of the Action Plan of the Tri-Party Agreement. 


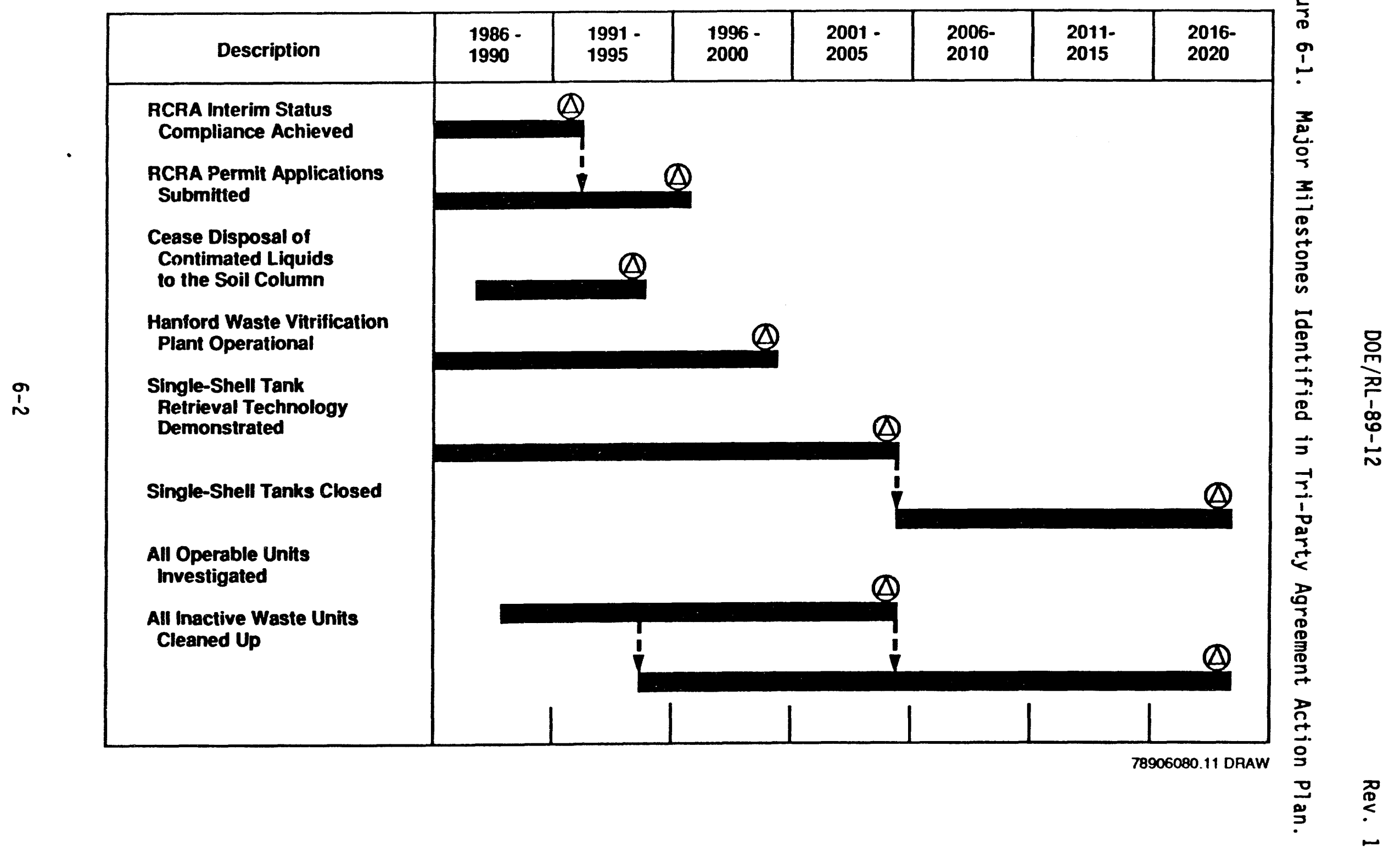




\subsection{DECONTAMINATION AND DECOMMISSIONING ACTIVITIES}

In addition to hazardous waste control under RCRA/CERCLA and current waste management activities, surplus buildings and other structures (reactors, support buildings, etc.) contaminated with radioactive materials must be dismantled and decontaminated. The majority of these facilities were built in the 1940's as part of the Manhattan Project and are mainly located in the 100 and 200 Areas. These facilities include eight plutonium production reactors, two chemical separations/processing plants, and ancillary support structures that contain residual radioactive contamination. There are 115 such structures currently identified. Dismantling and decontamination is conducted under the Hanford surplus facilities program.

Generally, decontamination and decommissioning can be considered a source-control strategy for groundwater protection. Removal of these sources diminishes the potential for long-term groundwater contamination. Groundwater protection provisions al so needing consideration during decontamination and decommissioning include wash or rinse water containment and long-term leachability of residual contaminants in the soil column. These are especially important for locations near the Columbia River where the vadose zone is of limited thickness. Other special source considerations include the presence of the long-lived radionuclides in the graphite cores of the old plutonium production reactors $\left(e . g .,{ }^{14} \mathrm{C}\right.$ and ${ }^{36} \mathrm{Cl}$ [half-lives of 5,700 and 200,000 years, respectively]). If these are removed and disposed of on the 200 Areas Plateau, some type of engineered barrier system may be needed. Such groundwater protection considerations have been made in the EIS, such as for the decommissioned plutonium production reactors. Additionally, the groundwater protection provisions of 40 CFR 193, "Environmental standards for the Management, Storage, and Land Disposal of Low-Level Radioactive Waste and Naturally Occurring and Accelerator-Produced Radioactive Waste," and state regulations (see Section 4.2) will apply.

Most of the cleanup and verification (or postclosure monitoring) is conducted under NEPA, for which project plans are prepared for each waste site or structure. Groundwater monitoring plans do not appear to be required as a standard course of action for the decontamination and decommissioning program as described above. They may be needed in special cases, however, if 1 arge amounts of rinsate or decontamination water are likely to be discharged to the ground or if long-term performance assessments indicate the likelihood of transport to groundwater.

Groundwater-related activities in the Hanford surplus facilities program will be coordinated with the Well Administrator Team and GWG to ensure consistency with other groundwater programs. 
Rev. 1

This page intentionally left blank. 


\subsection{IMPLEMENTATION SCHEDULE}

Many of the activities satisfying the GPMP elements specified in DOE Order 5400.1 (III) are also addressed in plans and schedules associated with the Tri-Party Agreement milestones. However, some data needs and activities are not covered by existing plans. The schedule outline of Table 8-1 addresses the additional information and organizational needs, as discussed previously, and within Tiger Team audit findings.

Implementation of GPMP elements will be jointly coordinated by the GWG and through RL oversight. The two groups will meet regularly to ensure implementation occurs and that requirements of the plan are met. This bilateral entity will replace the formerly proposed Office of Groundwater Protection Management. Implementation of those activities not included in Tri-Party Agreement milestones, state regulations, or safety issues will depend on funding availability. 
Table 8-1. GPMP Activities and Implementation Schedule.

\begin{tabular}{|c|c|c|}
\hline Program element & $\begin{array}{l}\text { Adminiatrating } \\
\text { ontity(8) }\end{array}$ & $\begin{array}{l}\text { Dete(s) of } \\
\text { implementation }\end{array}$ \\
\hline \multicolumn{3}{|l|}{ 1. Program Integration: } \\
\hline $\begin{array}{l}\text { A. Prepere groundwater sections of ennual Integreted } \\
\text { Hanford Site Environmental Monitoring Plen. }\end{array}$ & PNL & $\begin{array}{l}\text { Annually, in } \\
\text { November }\end{array}$ \\
\hline $\begin{array}{l}\text { B. Review/revise Groundwater Protection Management } \\
\text { Program document. }\end{array}$ & WHC, RL & $\begin{array}{l}\text { Annually (review) } \\
\text { and triennially } \\
\text { (revision) }\end{array}$ \\
\hline C Prepere annual groundwater quality/status report. & WHC, PNL & $\begin{array}{l}\text { Annually, beginning } \\
\text { in FY } 1983\end{array}$ \\
\hline D. Prepare Operational Groundwater Status Report & WHC & Annually \\
\hline E. Porticipate in Well Administrator Team. & $\begin{array}{l}\text { PNL, RL, WHC, } \\
\text { U.S. Goological } \\
\text { Survey, U.S. Army } \\
\text { Corps of Engineers }\end{array}$ & Bimonthly, ongoing \\
\hline F. Porticipate in Geohydrologic Working Group meetings. & $\begin{array}{l}\text { PNL, RL, WHC, } \\
\text { U.S. Geologicel } \\
\text { Survey }\end{array}$ & Monthly, ongoing \\
\hline \multicolumn{3}{|l|}{ 2. Characterization of Geohydrologic Regime: } \\
\hline $\begin{array}{l}\text { A. Evaluate existing, unincorporated data; both older and } \\
\text { current work on geology and hydrogeology of the } \\
\text { Pesco Besin. }\end{array}$ & WHC, PNL & Continuous, ongoing \\
\hline B. Drill new hydrogeologic cheracterization boraholes. & PNL, WHC & $\begin{array}{l}\text { Ongoing and } \\
\text { currently proposed }\end{array}$ \\
\hline C. Conduct borehole logging. & WHC, PNL & $\begin{array}{l}\text { Continuous, } \\
\text { beginning in } \\
\text { FY } 1893\end{array}$ \\
\hline $\begin{array}{l}\text { D. Eveluste recharge-discharge boundaries, surface } \\
\text { runoff, infiltration, and conduct vadose zone } \\
\text { monitoring. }\end{array}$ & PNL, WHC & Continuous, ongoing \\
\hline $\begin{array}{l}\text { E. Conduct sitewide conceptual/numerical groundwater } \\
\text { modeling. }\end{array}$ & WHC & Continuous, ongoing \\
\hline F. Conduct surfece goologic mopping. & WHC & Continuous, ongoing \\
\hline $\begin{array}{l}\text { G. Evaluate woter-level date from deep basalt piezometers } \\
\text { (in conjunction with (A) and (B) above. }\end{array}$ & PNL, WHC & Continuous, ongoing \\
\hline
\end{tabular}

FY = fiscol yoar.

PNL = Pacific Northwest Laboratory.

$R L=$ U.S. Depertment of Energy, Richlend Operations Office.

WHC $=$ Westinghouse Hanford Company. 


\subsection{REFERENCES}

10 CFR 61, "Licensing Requirements for Land Disposal of Radioactive Waste," Code of Federal Regulations, as amended.

40 CFR 61, "National Emission Standards for Hazardous Air Pollutants," Code of Federal Regulations, as amended.

40 CFR 122, "EPA Administered Permit Programs: The National Pollutant Discharge Elimination System," Code of Federal Regulations, as amended.

40 CFR 123, "State Program Requirements," Code of Federal Regulations, as amended.

40 CFR 124, "Procedures for Decisionmaking," Code of Federal Regulations, as amended.

40 CFR 125, "Criteria and Standards for the National Pollutant Discharge Elimination System," Code of Federal Regulatiors, as amended.

40 CFR 129, "Toxic Pollutant Effluent Standards," Code of Federal Regulations, as amended.

40 CFR 130, "Water Quality Planning Management," Code of Federal Regulations, as amended.

40 CFR 144, "Underground Injection Control Program," Code of Federal Regulations, as amended.

40 CFR 145, "State UIC Program Requirements," Code of Federal Regulations, as amended.

40 CFR 146, "Underground Injection Control Program: Criteria and Standards," Code of Federal Regulations, as amended.

40 CFR 147, "State Underground Injection Control Programs," Code of Federal Regulations, as amended.

40 CFR 148, "Hazardous Waste Injection Restrictions," Code of Federal Regulations, as amended.

40 CFR 149, "Sole Source Aquifers," Code of Federal Regulations, as amended.

40 CFR 149.3, "Criteria for Identifying Critical Aquifer Protection Areas," Code of Federal Regulations, as amended.

40 CFR 162, "State Registration of Pesticide Products," Code of Federal Regulations, as amended.

40 CFR 163, "Certification of Usefulness of Pesticide Chemicals," Code of Federal Regulations, as amended. 
40 CFR 164, "Rules of Practice Governing Hearings, under the Federal Insecticide, Fungicide, and Rodenticide Act, Arising from Refusals to Register, Cancellations of Registrations, Changes of Classifications, Suspensions of Registrations and Other Hearings Called Pursuant to Section 6 of the Act," Code of Federal Regulations, as amended.

40 CFR 165, "Regulations for the Acceptance of Certain Pesticides and Recommended Procedures for the Disposal and Storage of Pesticides and Pesticide Containers," Code of Federal Regulations, as amended.

40 CFR 191, "Envi, onmental Radiation Protection Standards for Management and Disposal of spent Nuclear Fue1, High-Level and Transuranic Radioactive Wastes," Code of Federal Regulations, as amended.

40 CFR 192, "Health and Environmental Protection Standards for Uranium and Thorium Mill Tailings," Code of Federal Regulations, as amended.

40 CFR 193 (Proposed), "Environmental Standards for the Management, Storage, and Land Disposal of Low-Level Radioactive Waste and Naturally Occurring and Accelerator-Produced Radioactive Waste," Code of Federal Regulations, as amended.

40 CFR 260, "Hazardous Waste Management System-General," Code of Federal Regulations, as amended.

40 CFR 264, "Standards for Owners and Operators of Hazardous Waste Treatment, Storage, and Disposal Facilities," Code of Federal Regulations, as amended.

40 CFR 265, "Interim Status Standards for Owners and Operators of Hazardous Waste Treatment, Storage, and Disposal Facilities," Code of Federal Regulations, as amended.

40 CFR 267, "Interim Standards for Owners and Operators of New Hazardous Waste Land Disposal Facilities," Code of Federal Regulations, as amended.

40 CFR 300-373, "Subchapter J - Superfund, Emergency Planning, and Community Right-to-Know Programs," Code of Federal Regulations, as amended.

40 CFR 761, "Polychlorinated Biphenyls (PCBs) Manufacturing, Processing, Distribution in Commerce, and Use Prohibitions," Code of Federal Regulations, as amended.

Adams, M. R., and N. R. Wing, 1986, Protective Barrier and Warning Marker System Development Plan, RHO-RE-PL-35P, Rockwell Hanford Operations, Richland, Washington.

Atomic Energy Act of 1954, 42 USC 2011 et seq.

Chamness, M. A., and J. K. Merz, 1993, Hanford Wells, PNL-8800, Pacific Northwest Laboratory, Richiand, Washington.

Clean Water Act of 1977,33 USC 1251 et seq. 
Comprehensive Environmental Response, Compensation, and Liability Act of 1980, 42 USC 9601 et seq.

Department of Community Development, 1990, A Growth Strategy for Washington State--Final Report, Washington State Growth Strategies Commission, olympia, Washington.

DOE, 1984, Radioactive Waste Management - Guidance Document, DOE Order 5820.2A, U.S. Department of Energy, Washington, D.C.

DOE, 1987, Final Environmental Impact Statement, Disposal of Hanford Defense High-Level, Trunsuranic, and Tank Waste, Hanford Site, Richland, Washington, DOE/EIS-0113, 5 Volumes, U.S. Department of Energy, Washington, D.C.

DOE, 1988, General Environmental Protection Progran, DOE Order 5400.1, U.S. Department of Energy, Washington, D.C.

DOE, 1990, Radiation Protection of the Public and the Environment, DOE Order 5400.5, U.S. Department of Energy, Washington, D.C.

DOE-RL, 1988, Hanford Waste Management Program Plan, DOE/RL 88-33, U.S. Department of Energy, Richland Operations Office, Richland, Washington.

DOE-RL, 1992a, Environmental Protection Implementation Plan, DOE/RL-91-49, U.S. Department of Energy, Richland Operations Office, Richland, Washington.

DOE-RL, 1992b, Hanford Site Groundwater Background, DOE/RL-92-23, U.S. Department of Energy, Richland Field Office, Richland, Washington.

DOE-RL, 1993, Hanford Site Background: Part 1, Soil Background for Nonradioactive Analytes, DOE/RL-92-24, U.S. Department of Energy, Richland Field Office, Richland, Washington.

Ecology, 1992, Statistical Guidance for Ecology Site Managers, Washington State Department of Ecology, Olympia, Washington.

Ecology and DOE, 1992, "In the matter of the compliance by United States Department of Energy with Chapter 70.105 and $90.48 \mathrm{RCW}$ and the Rules and Regulations of the Department of Ecology, " Consent Order DE 91 INM-177 (for the permitting of liquid effluent discharges under Washington Administrative Code 173-216), dated February 3, 1992, Washington State Department of Ecology, Olympia, Washington.

Ecology, EPA, and DOE, 1989, Hanford Federal Facility Agreement and Consent Order, 2 vols., Washington State Department of Ecology, U.S. Environmental Protection Agency, and the U.S. Department of Energy, Washington, D.C.

Endangered Species Act of 1973, 16 USC 1531 et seq.

Federal Insecticide, Fungicide, and Rodenticide Act of 1975, 7 USC 136 et seq. 
Johnson, V. G., 1993, Westinghouse Hanford Company Operational Groundwater Status Report, 1990-1992, WHC-EP-0595, Westinghouse Hanford Company, Richland, Washington.

Low-Level Radioactive Waste Policy Act of 1980, 42 USC 1201 et seq.

National Environmental Policy Act of 1969, 42 USC 4321 et seq.

Nuclear Waste Policy Act of 1982, 42 USC 10101 et seq.

RCW 90.44, "Regulation of Public Ground Waters," Revised Code of Washington, as amended.

RCW 90.48, "Coastal Waters Protection Act," Revised Code of Washington, as amended.

RCW 90.54, "Water Resources Act of 1971," Revised Code of Washington, as amended.

Resource Conservation and Recovery Act of 1976, 42 USC 6901 et seq.

Routson, R. C., and V. G. Johnson, 1988, Recharge Estimates for the Hanford Site 200 Areas Plateau, WHC-SA-0393-FP, Westinghouse Hanford Company, Richland, Washington.

Safe Drinking Water Act of 1974, 42 USC 300 f et seq.

Solid Waste Disposal Act of 1974, 42 USC $33 \mathrm{f}$ et seq.

Superfund Amendments and Reauthorization Act of 1986, 42 USC 6921 et seq.

Toxic Substances Control Act of 1976, 15 USC 2601 et seq.

Uranium Mill Tailings Radiation Control Act of 1978, 42 USC 2014 et seq.

WAC 173-100, "Ground Water Management Areas and Programs," Washington Administrative Code, as amended.

WAC 173-150, "Protection of Withdrawal Facilities Associated with Ground Water Rights," Washington Administrative Code, as amended.

WAC 173-154, "Protection of Upper Aquifer Zones," Washington Administrative Code, as amended.

WAC 173-160, "Minimum Standards for Construction and Maintenance of Wells," Washington Administrative Code, as amended.

WAC 173-200, "Water Quality Standards for Ground Waters of the State of Washington," Washington Administrative Code, as amended.

WAC 173-201, "Water Quality Standards for Surface Waters of the State of Washington," Washington Administrative Code, as amended. 
WAC 173-204-130, "Administrative Policies," Washington Administrative Code, as amended.

WAC 173-216, "State Waste Discharge Permit Program," Washington Administrative Code, as amended.

WAC 173-218, "Underground Injection Control Plan," Washington Administrative Code, as amended.

WAC 173-240, "Submission of Plans and Reports for Construction of Wastewater Facilities," Washington Administrative Code, as amended.

WAC 173-303, "Dangerous Waste Regulations," Washington Administrative Code, as amended.

WAC 173-303-645, "Releases From Sol id Waste Management Units," Washington Administrative Code, as amended.

WAC 173-303-9905, "Dangerous Waste Constituents List," Washington Administrative Code, as amended.

WAC 173-304, "Minimum Functional Standards for Solid Waste Handling," Washington Administrative Code, as amended.

WAC 173-340, "Model Toxics Control Act-Cleanup," Washington Administrative Code, as amended.

WAC 173-360, "Underground Storage Tank Regulations," Washington Administrative Code, as amended.

WAC 173-563, "Instream Resources Protection Program for the Main Stem Columbia River in Washington State," Washington Administrative Code, as amended.

WAC 173-564, "Water Resources Management Program for the Main Stem of the Snake River in Washington State," Washington Administrative Code, as amended.

WAC 246-272, "On-Site Sewage Disposal," Washington Administrative Code, as amended.

WAC 365-190, "Minimum Guidelines to Classify Agriculture, Forest, Mineral Lands, and Critical Areas," Washington Administrative Code, as, amended.

WHC, 1990, Strategy for Handling and Disposal of Purgewater at the Hanford site, Washington, WHC-MR-0039, Westinghouse Hanford Company, Richiand, Washington.

WHC, 1993a, Hanford Well Remediation and Decommissioning Plan, WHC-SD-EN-AP-122, Rev. O, Westinghouse Hanford Company, Richland, Washington.

WHC, 1993b, Westinghouse Hanford Company Operation Groundwater Status Report, WHC-EP-0595, Westinghouse Hanford Company, Richland, Washington. 


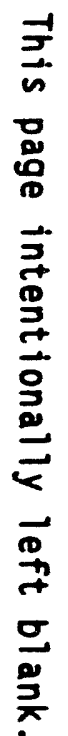

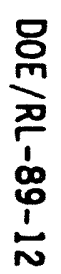

?ᄁ: 
HANFORD SITE AGREEMENT MANAGEMENT STRUCTURE 
This page intentionally left blank. 
HANFORD SITE AGREEMENT MANAGEMENT STRUCTURE

\section{A1.0 GENERAL SITE INFORMATION}

\section{A1.1 ORGANIZATION AND ADMINISTRATION}

The U.S. Department of Energy (DOE) Assistant Secretary of Defense Programs is responsible for managing waste that is either generated by defense programs or is accepted through negotiations with other government entities. The Assistant Secretary of Defense Programs has the authority for establishing policy for the management of DOE waste and ensuring that DOE waste within the purview of defense programs is managed according to the requirements of $D O E$ Order 5820.2A (DOE 1984).

The Hanford Site is administered by the DOE through the DOE, Richland Operations Office (RL), located in Richland, Washington. The Manager, RL, is responsible for all activities that affect the treatment, storage, or disposal (TSD) of waste at the Hanford Site. This responsibility is delegated to the Assistant Manager for Operations, and further to the Director of Waste Management Division. The Deputy Manager for Environment is responsible for ensuring compliance with environmental statutes and regulations through the Office of Environmental Assurance, Permits and Policy. Figure A-1 illustrates the $\mathrm{RL}$ organization.

Three prime contractors operate the Hanford Site: the Hanford Environmental Health Foundation, Pacific Northwest Laboratory (PNL), and Westinghouse Hanford Company (WHC). Boeing Complicer Services, Richiand is contracted to RL along with WHC. Kaiser Engineers Hanford is subcontracted to WHC. All of these contractors generate regulated waste; it is either radioactive and subject to the requirements pursuant to the Atomic Energy Act of 1954 as amended, or it is hazardous and subject to the regulations pursuant to the Resource Conservation and Recovery Act of 1976 (RCRA), as amended. Only PNL and WHC are responsible for manaing the TSD of regulated waste.

WHC, as the Operating and Engineering Contractor for the Hanford Site, is directly responsible for the management of regulated waste. PNL is responsible for portions of the research and development associated with the management of regulated waste and has the lead responsibility for away-fromfacility environmental monitoring.

The WHC organizational structure is shown in Figure A-2. Facility Operations is the principal organization with responsibility and authority for the operation of facilities for regulated waste. Restoration and Remediation is responsible for the strategy and negotiations associated with obtaining regulatory permits for certain facilities, for coordination of permit application preparation, and for regulatory compliance activities. Environmental Safety, Health, and Quality Assurance is responsible for oversight in all activities. 


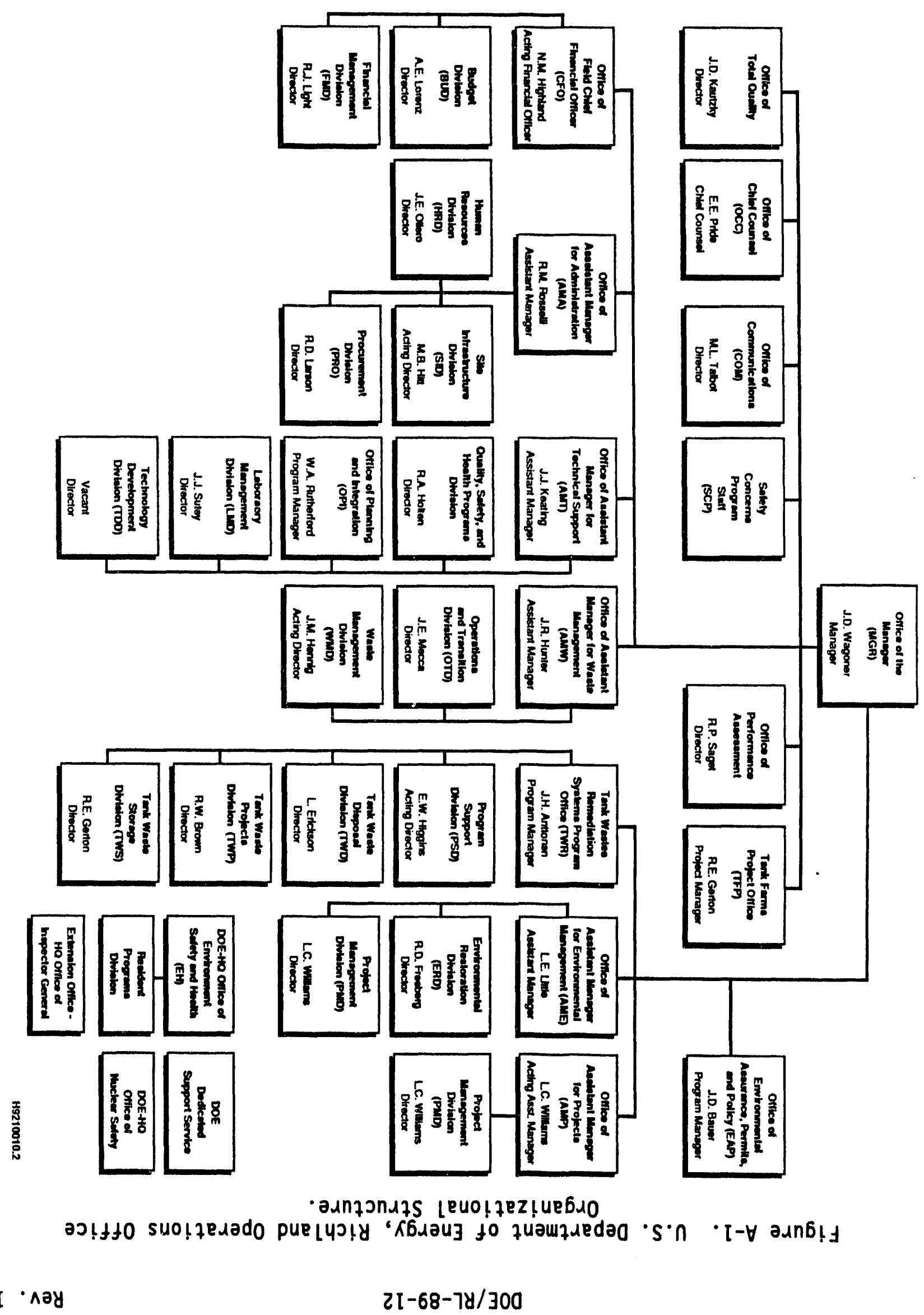




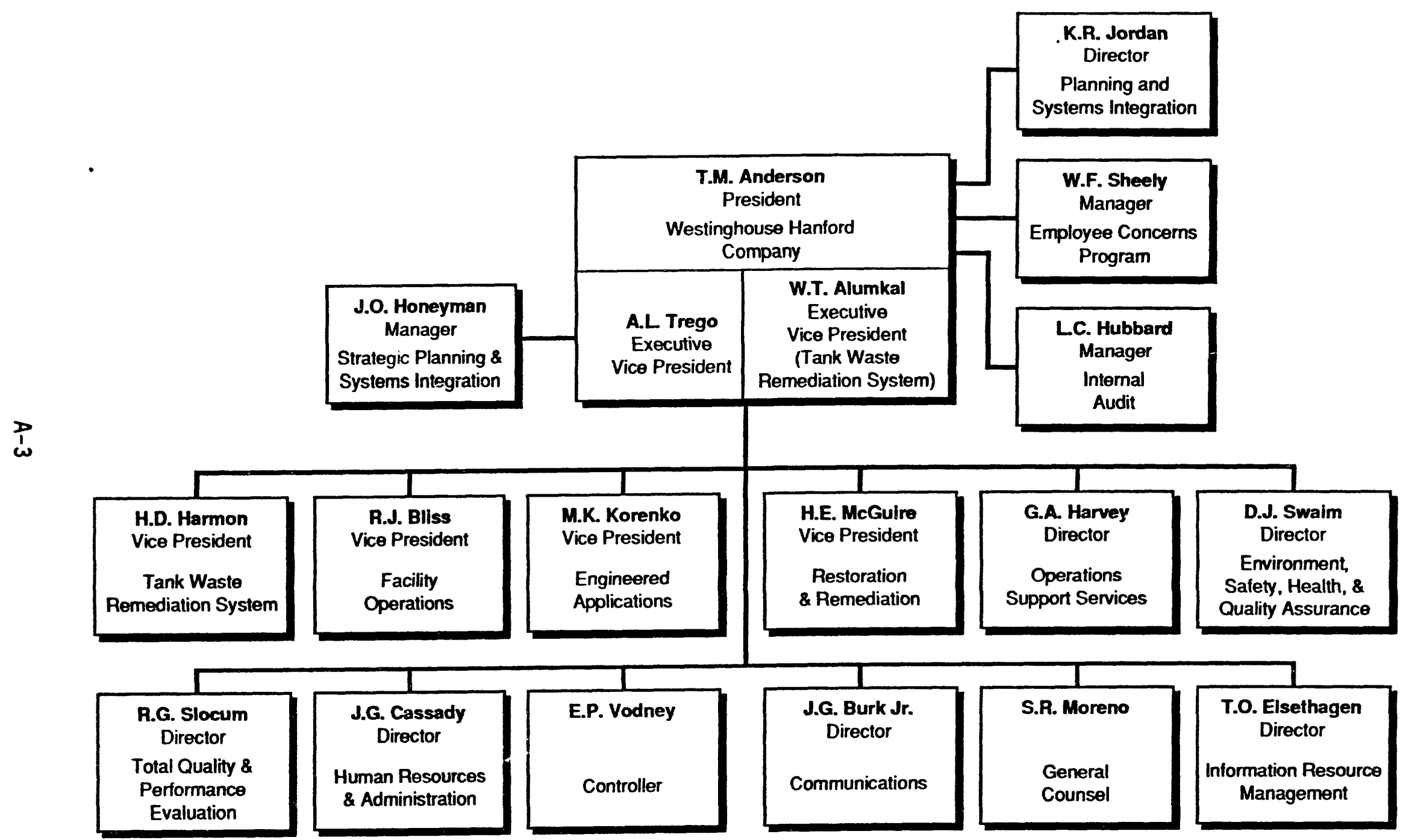

(1)

H9210005.1 
The PNL organizational structure is shown in Figure A-3. Much of the research and development for the Hanford Waste Vitrification Plant and the Grout Treatment Facility, two major treatment facilities at the Hanford Site, is accomplished by PNL. To a lesser extent, three other departments contribute to some technical aspects for regulated waste: Earth and Environmental Sciences Center, Material and Chemical Sciences Center, and Office of Technology Planning and Analysis. The PNL also has specific responsibilities for environmental surveillance and monitoring. Facilities and Operations has responsibility for storage of mixed waste or hazardous waste generated by PNL.

$\mathrm{RL}$, in association with the Hanford Site contractors, interfaces with several governmental agencies both at the federal and state levels. These agencies include the U.S. Environmental Protection Agency (EPA), the EPA regional office in Seattle, Washington, the Washington State Department of Ecology (Ecology), and the U.S. Nuclear Regulatory Commission (NRC).

EPA has authorized Ecology to regulate the TSD of hazardous waste and the hazardous constituents of mixed waste and remedial actions at inactive sites and facilities at the Hanford Site. RL has agreed with EPA and Ecology to cover RCRA regulatory actions and Comprehensive Environmental Response, Compensation, and Liability Act of 1980/Superfund Amendments and

Reauthorization Act of 1986 (CERCLA/SARA) remedial actions. This agreement establishes the basis for a long-term regulatory compliance strategy.

The NRC has licensing jurisdiction for facilities expressly authorized for disposal of high-level waste. Coordination is maintained with the NRC, as appropriate, to ensure compliance with applicable regulations. 


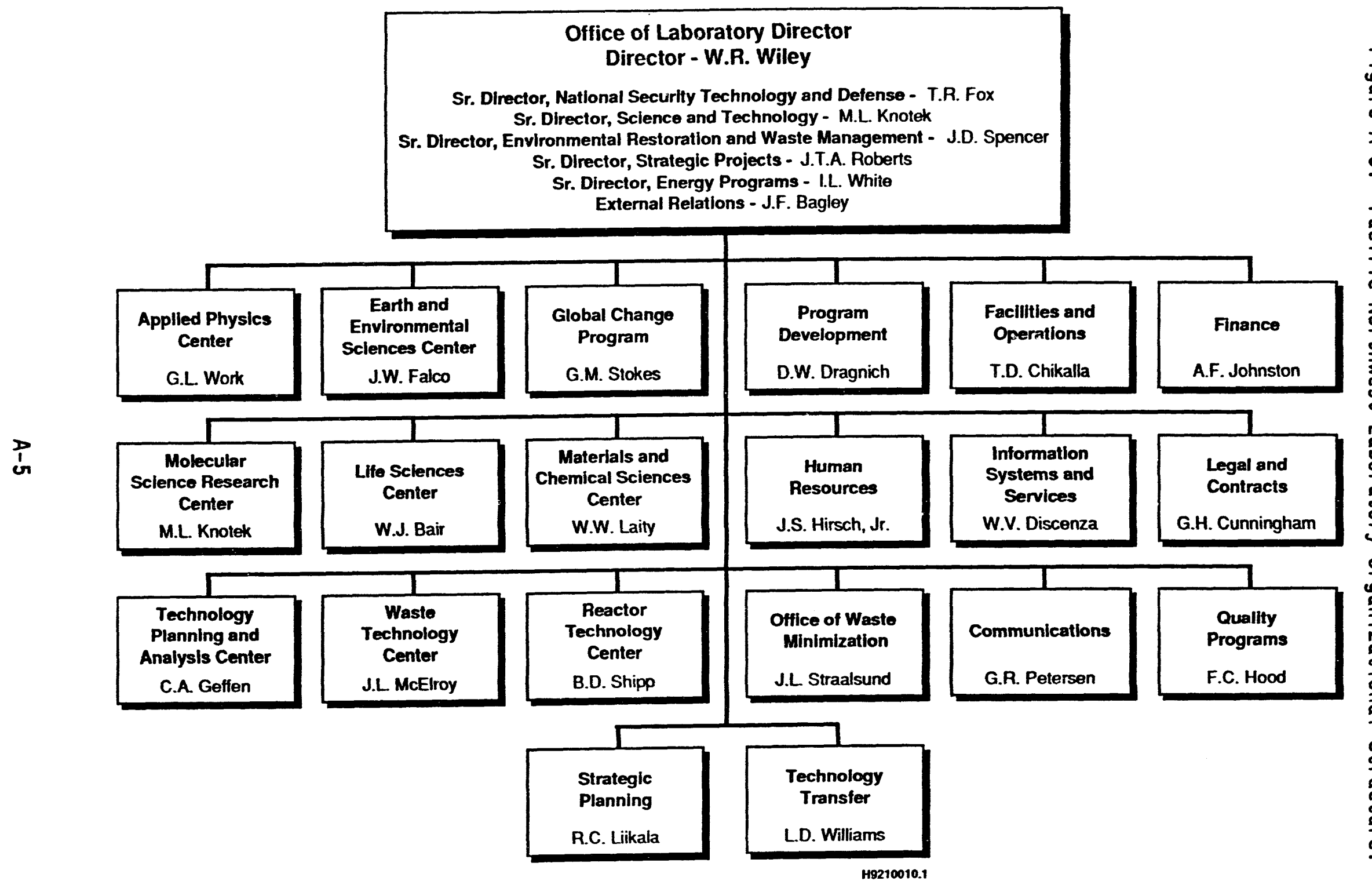




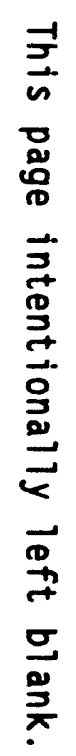

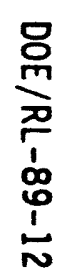

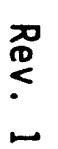




\section{A2.0 TRI-PARTY AGREEMENT PROJECT MANAGENENT DESCRIPTION}

\section{A2.1 PROJECT MANAGERS}

The EPA, DOE, and Ecology shall each designate one individual who will serve as project manager and the primary point of contact for all activities to be carried out under this action plan.

The primary responsibilities for the project managers are as follow:

- Implement the scope, terms, and conditions of this action plan

- Approve annual work schedule updates and other revisions

- Direct and provide guidance to unit managers

- Maintain effective communication among the project managers and report status to respective management.

Subject to the limitations set forth in Article XXXVII o? 'he Hanford Federal Facility Agreement and Consent Order (Tri-Party Agreement) (Ecology et al. 1989), in addition to other authorities and responsibilities, Ecology and EPA project managers, or their designated representative(s), shall have authority to: (1) take samples, request split samples of the DOE samples, and ensure that work is performed properly and pursuant to EPA protocols as well as pursuant to the attachments and plans incorporated into this agreement; (2) observe all activities performed pursuant to this agreement, take photographs, and make sure other reports are prepared on the progress of the work as the project manager deems appropriate; and (3) review records, files, and documents relevant to this agreement. In addition, the project manager for EPA or Ecology has authority to require changes to any procedural, design, or specification document that is referenced in a supporting work plan. Such required changes will be subject to the appropriate dispute resolution process as specified in the Tri-Party Agreement.

The DOE project manager or his or her representative shall be physically present on the Hanford Site or reasonably available to supervise work performed at the Hanford Site pursuant to this agreement and shall be available to EPA and Ecology project managers for the pendency of this agreement.

Other authorities and responsibilities are identified in the context of this action plan. The project managers may delegate their authority and responsibilities to the unit managers as appropriate. Table A-1 provides a listing of Hanford Site technical resources.

\section{A2.2 UNIT MANAGERS}

EPA, DOE, and Ecology shall each designate an individual as a unit manager for each operable unit, each TSD group/unit, or other specific Tri-Party Agreement activity in which they participate. Unit managers will 
Table A-1. Hanford Site Remedial Investigation/Feasibility Study Technical Resources.

\begin{tabular}{|c|c|c|}
\hline \multirow{2}{*}{ Subject/activity } & \multicolumn{2}{|c|}{ Technical resources } \\
\hline & Remedial investigation & Feasibility study \\
\hline Hydrology and geology & $\begin{array}{l}\text { WHC/Geosciences; PNL/Earth } \\
\text { and Environmental Sciences } \\
\text { Center }\end{array}$ & WHC/Geosciences \\
\hline $\begin{array}{l}\text { Toxicology and risk/ } \\
\text { endangerment } \\
\text { assessment }\end{array}$ & $\begin{array}{l}\text { WHC/Environmental Technology; } \\
\text { PNL/Earth and Environmental } \\
\text { Sciences Center; PNL/Life } \\
\text { Sciences Center }\end{array}$ & $\begin{array}{l}\text { WHC/Environmental } \\
\text { Technology }\end{array}$ \\
\hline $\begin{array}{l}\text { Environmental } \\
\text { chemistry }\end{array}$ & $\begin{array}{l}\text { WHC/Geosciences; PNL/Earth } \\
\text { and Environmental Sciences } \\
\text { Center }\end{array}$ & WHC/Geosciences \\
\hline $\begin{array}{l}\text { Geotechnical and } \\
\text { civil engineering }\end{array}$ & $\begin{array}{l}\text { WHC/Geosciences (Planning) } \\
\text { Environmental Field Services }\end{array}$ & NA \\
\hline $\begin{array}{l}\text { Geotechnical and } \\
\text { civil engineering }\end{array}$ & NA & $\begin{array}{l}\text { WHC/Environmental } \\
\text { Engineering; PNL/Waste } \\
\text { Technology Center }\end{array}$ \\
\hline $\begin{array}{l}\text { Groundwater treatment } \\
\text { engineering }\end{array}$ & NA & $\begin{array}{l}\text { WHC/Environmental } \\
\text { Engineering; PNL/Waste } \\
\text { Technology Center }\end{array}$ \\
\hline $\begin{array}{l}\text { Waste stabilization } \\
\text { and treatment }\end{array}$ & NA & $\begin{array}{l}\text { WHC/Environmental } \\
\text { Engineering; PNL/Waste } \\
\text { Technology Center }\end{array}$ \\
\hline Surveying & Kaiser Engineers Hanford & NA \\
\hline $\begin{array}{l}\text { Soil and water } \\
\text { sampling and analysis }\end{array}$ & $\begin{array}{l}\text { WHC/Environmental } \\
\text { Engineering; Westinghouse } \\
\text { Office of Sampling } \\
\text { Management; PNL/Earth and } \\
\text { Environmental Sciences } \\
\text { Center; PNL/Materials and } \\
\text { Chemical Sciences Center }\end{array}$ & NA \\
\hline $\begin{array}{l}\text { Drilling and well } \\
\text { installation }\end{array}$ & $\begin{array}{l}\text { WHC/Geosciences Environmental } \\
\text { Field Services; Kaiser } \\
\text { Engineers Hanford }\end{array}$ & NA \\
\hline Radiation monitoring & $\begin{array}{l}\text { WHC/Operational Health } \\
\text { Physics }\end{array}$ & NA \\
\hline
\end{tabular}

$N A=$ Not applicable.

PNL = Pacific Northwest Laboratory.

WHC = Westinghouse Hanford Company. 
only be identified for those areas where effort is ongoing or planned in the near future. A listing of currently assigned unit managers from all three parties shall be maintained and distributed to all parties by the DOE project manager. Each unit manager shall represent his/her respective party and keep his/her project manager informed on the status and any problems that arise.

In general, EPA and Ecology will both assign a unit manager to each operable unit or separate TSD group/unit. The unit manager from the lead regulatory agency (see Section 5.6 of main document for discussion of lead regulatory agency) shall be responsible for regulatory oversight of all activities required by this action plan for that operable unit or TSD group/unit.

The unit manager from the supporting regulatory agency shall serve as a liaison for his/her agency and shall stay informed of the general status of issues and problems encountered at the operable unit. The unit manager for the supporting regulatory agency shall be responsible for making decisions related to issues for which the supporting regulatory agency maintains authority. All such decisions shall be made in consideration of recommendations made by the unit manager for the lead regulatory agency. 
Rev. 1

This page intentionally left blank. 


\section{A3.0 PROJECT ORGANIZATION AND RESPONSIBILITIES FOR CERCLA ACTIVITIES}

The project organization is shown in Figure A-4. The following paragraphs describe the responsibilities of the individuals shown in Figure A-4.

Project Managers. EPA, DOE, and Ecology will each designate one individual as project manager who will serve as the primary point of contact for a!l activities to be carried out under the Tri-Party Agreement and Action Plan.

Unit Managers. EPA, DOE, and Ecology will each designate an individual as a unit manager for each operable unit or separate TSD group/unit. The unit manager from the lead regulatory agency will be responsible for regulatory oversight of all activities required. The unit from the supporting regulatory agency will be responsible for making decisions related to issues for which the supporting regulatory agency maintains authority. All such decisions will be made in consideration of recommendations by the unit manager from the lead regulatory agency. The unit manager from DOE will be responsible for maintaining and controlling the schedule and budget and keeping the EPA and Ecology unit managers informed as to the status of these activities, particularly the status of agreements and commitments.

Quality Assurance Officer. The Quality Assurance Officer is responsible for monitoring overall Environmental Restoration Program activities through establishment of Hanford Site quality assurance auditing program controls that may be appropriately applied to the remedial activities. The Quality Assurance officer is specifically vested with the organizational independence and authority to identify conditions adverse to quality, and to systematically seek effective corrective action.

Health and Safety Officer. The Health and Safety Officer is responsible for monitoring all potential health and safety hazards, including those associated with radioactive, volatile, and/or toxic compounds during sample handling and sampling decontamination activities. The Health and Safety Officer has the responsibility and authority to halt field activities resulting from unacceptable health and safety hazards.

Technical Lead. The technical lead will be a designated person within the Westinghouse Hanford Environmental Restoration Engineering Group. The responsibilities of the technical lead will be to plan, authorize, and control work so that it can be completed on schedule and within budget, and to ensure that all planning and work performance activities are technically sound.

Remedial Investigation/Feasibility Study Coordinators. The remedial investigation (RI) and feasibility study (FS) coordinators will be responsible for coordinating all activities related to the RI and FS, respectively, including data collection, analysis, and reporting. The RI/FS coordinators will be responsible for keeping the technical lead informed to the RI and FS work status and any problems that may arise. 
Figure A-4. Project Organization.

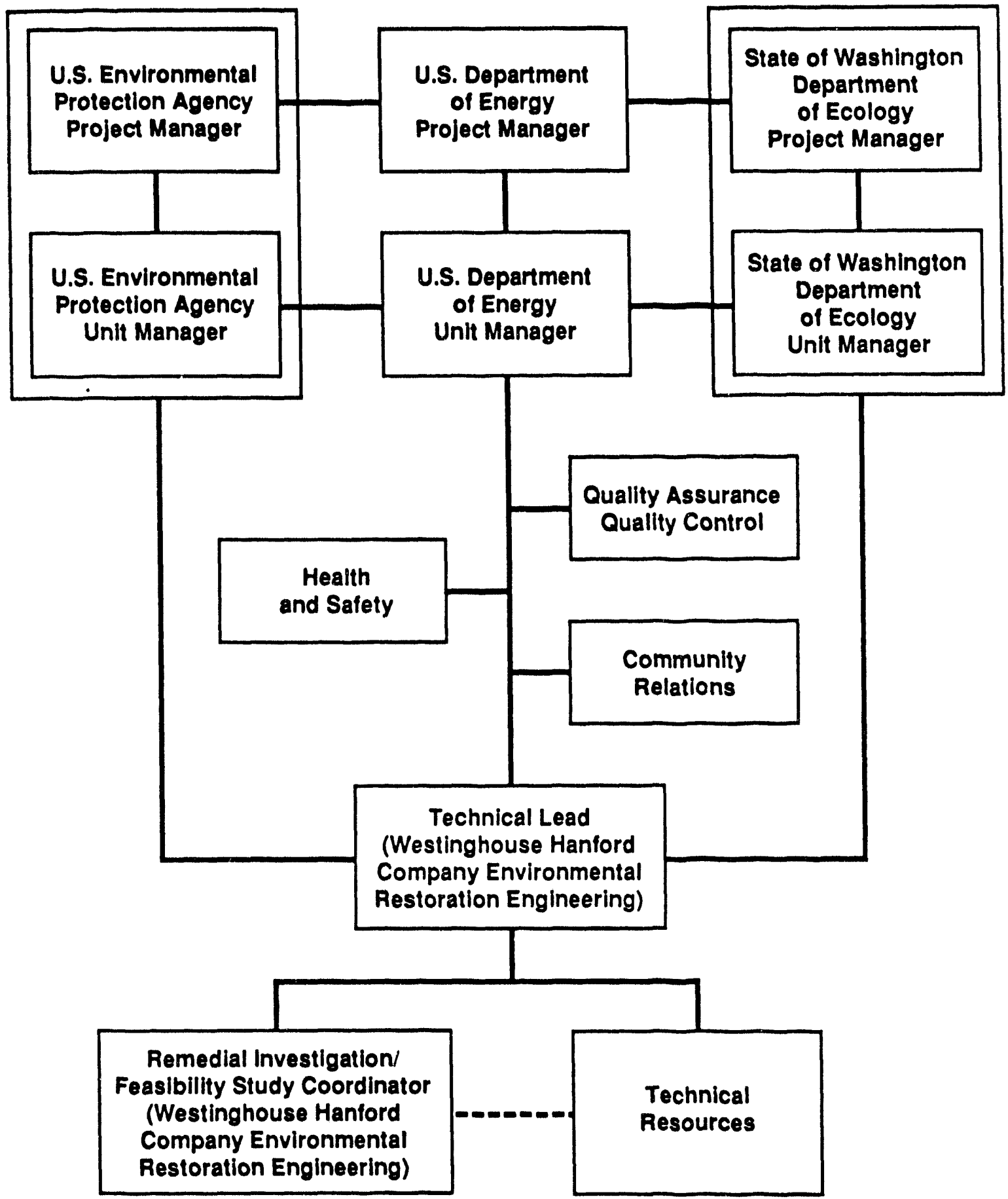

Legend

-..- Communications and Support Functions

Reporting Functions

H9209022.2 


\section{A4.0 REFERENCES}

Atomic Energy Act of 1954, 42 USC 2011 et seq.

Comprehensive Environmental Response, Compensation, and Liability Act of 1980, 42 USC 9601 et seq.

DOE, 1984, Radioactive Waste Management - Guidance Document, DOE Order 5820.2A, U.S. Department of Energy, Washington, D.C.

Ecology, EPA, and DOE, 1989, Hanford Federal Facility Agreement and Consent Order, 2 vols., Washington State Department of Ecology, U.S. Environmental Protection Agency, and the U.S. Department of Energy, Washington, D.C.

Resource Conservation and Recovery Act of 1976, 42 USC 6901 et seq.

Superfund Amendments and Reauthorization Act of 1986, 42 USC 6921 et seq. 
This page intentionally left blank. 


\section{DISTRIBUTION}

\section{Number of copies}

\section{ONSITE}

15

U.S. Department of Enerqy. Richland Operations Office

J. K. Erickson

R. D. Freeberg

M. J. Furman (5)

E. D. Goller

J. D. Goodenough

R. D. Hildebrand

R. G. McLeod

P. M. Pak

R. K. Stewart

K. M. Thompson

RL Public Reading Room

Pacific Northwest Laboratory

R. W. Bryce

M. J. Graham

G. V. Last

S. P. Luttrell

Technical Files

\section{Westinghouse Hanford Company}

M. R. Adams

D. B. Barnett (10)

P8-55

L. C. Brown

J. A. Caggiano

J. W. Cammann

R. A. Carlson

G. D. Carpenter

L. P. Diediker

W. T. Dixon

J. J. Dorian

J. W. Fassett

K. R. Fecht

B. H. Ford

K. A. Gano

M. G. Gardner

C. J. Geier

E. M. Greager

M. C. Hagood

W. H. Hamilton

H6-01

H6-06

H6-2O

H6-06

H4-14

H6-03

H6-30

T1-30

B2-17

H6-30

H6-06

H6-06

H6-06

$X 0-21$

N3-06

R2-50

H6-30

H6-04

N3-10

R. P. Henckel

H6-02

F. N. Hodges

H6-06

D. G. Horton

H6-06 


\section{DISTRIBUTION (cont)}

\section{Number of copies}

ONSITE

\section{Westinghouse Hanford Company (cont)}

$\begin{array}{ll}\text { M. C. Hughes } & \text { R2-81 } \\ \text { G. W. Jackson } & H 6-21 \\ \text { R. L. Jackson } & H 6-06 \\ \text { V. G. Johnson } & H 6-06 \\ \text { W. L. Johnson } & H 6-04 \\ \text { C. H. Kindle } & H 6-05 \\ \text { A. J. Knepp } & H 6-06 \\ \text { M. J. Lauterbach } & H 6-01 \\ \text { A. G. Law } & H 6-06 \\ \text { R. K. Ledgerwood } & \text { N3-05 } \\ \text { R. E. Lerch } & B 3-63 \\ \text { D. J. Moak } & N 3-05 \\ \text { S. M. O' Toole } & H 5-38 \\ \text { R. E. Peterson } & H 6-06 \\ \text { W. H. Price } & N 3-05 \\ \text { J. S. Schmid } & H 6-06 \\ \text { D. J. Sommer } & H 5-49 \\ \text { L. C. Swanson } & H 6-06 \\ \text { R. R. Thompson } & H 6-32 \\ \text { D. K. Tyler } & H 6-06 \\ \text { T. B. Veneziano } & L 4-96 \\ \text { J. L. Waite } & B 2-35 \\ \text { T. M. Wintczak } & H 6-27 \\ \text { J. G. Woolard } & H 6-05 \\ \text { M. T. York } & H 6-32 \\ \text { Central Files } & L 8-04 \\ \text { Document Processing and } & \\ \text { Distribution (2) } & L 8-15 \\ \text { EDMC (11) } & H 4-51 \\ \text { Information Release } & \\ \text { Administration } & H 4-17 \\ \text { WHC Geosciences Library (11) } & H 6-06\end{array}$



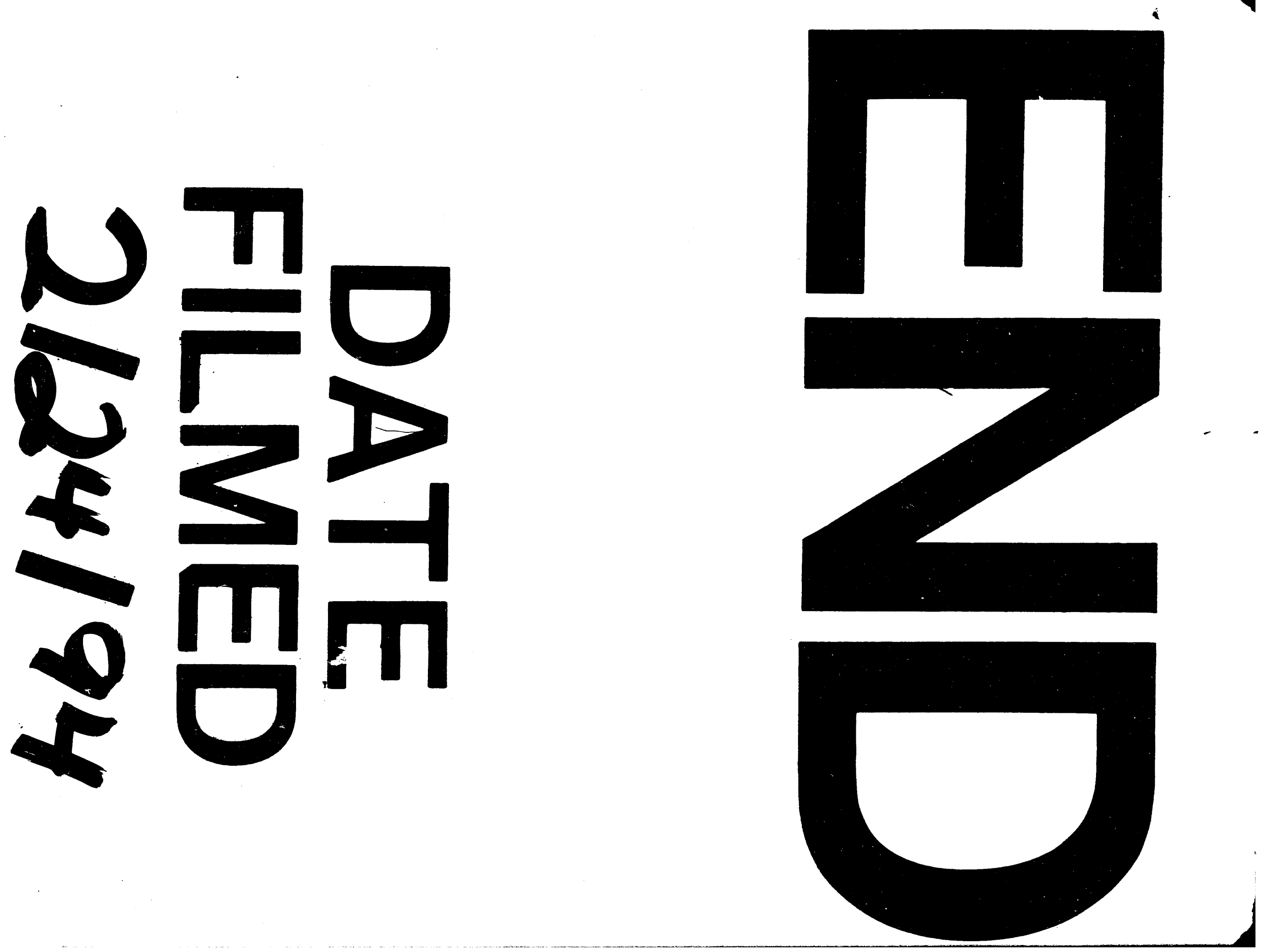
